\title{
Factors affecting spatial variability in seine net catches of fish in the surf zone of False Bay, South Africa
}

\author{
B. M. Clark*, B. A. Bennett, S. J. Lamberth \\ Zoology Department and Marine Biology Research Institute, University of Cape Town, Rondebosch 7700, South Africa
}

\begin{abstract}
Ichthyofaunal assemblages at 11 surf zone localities along the perimeter of False Bay, South Africa, were sampled by seine netting at monthly intervals between July 1991 and June 1993. Sampling localities were selected to encompass as wide a range of physical variables as possible, incorporating sheltered, exposed, sandy and mixed-shore habitats, thus providing a comprehensive assessment of the factors influencing surf zone fish assemblages. Data collected at each site were averaged over the 2 yr period in order to highlight the influence of various physical environmental variables on the abundance and community structure of these assemblages. Atherina breviceps, Liza richardsonif and Rhabdosargus globiceps were numerically dominant at all sites, together providing between 69 and $99 \%$ of the catches. Overall, catches of juvenile fish exceeded that of adult fish, making up almost $53^{\prime \prime}$, of the catch. Fish abundance (no. ind. per $100 \mathrm{~m}^{2}$ ) and number of species recorded at each site ranged from 6 to 199 and from 12 to 31 respectively. Multivariate analyses indicated that the degree of wave exposure, the presence of emergent rock on the shore and turbidity were responsible for most of the spatial variability in abundance and community structure observed. Although of lesser importance, abundance of detached macrophytes, salınity and water temperature also played a role in structuring fish assemblages. Species specific preferences for varying combinations of these variables are responsible for fluctuations in the structure and overall abundance of assemblages in different areas.
\end{abstract}

KEY WORDS: Surf zone fish - Spatial variability Environmental influences - Sandy beach - South Africa

\section{INTRODUCTION}

Ichthyofaunal assemblages inhabiting the surf zones of sandy beaches around the world have been studied in some detail (e.g. Warfel \& Merriman 1944, McFarland 1963, Edwards 1973, Gibson 1973, Lenanton et al. 1982, Lasiak 1984a, b, Senta \& Kinoshita 1985, Wright 1988). Although frequented by a wide variety of species, these habitats are typically dominated numerically by only a small number of forms: usually less than 10 species making up $>90 \%$ of the catch (e.g. Gunter 1958, McFarland 1963, Modde \& Ross 1981, Ross 1983, Lasiak 1984a, Bennett 1989a). The importance of these habitats as nursery areas for juvenile teleosts is well established (Warfel \& Merriman 1944, Gibson 1973. Modde 1980, Lasiak 1981, 1986, Robertson \& Lenanton

·E-mall:bclark@botzoo.uct.ac.za
1984) and is thought to rival that of estuaries in some areas (Lenanton 1982, Bennett 1989a, Potter et al. 1990).

Clearly, considerable progress has been made with respect to certain aspects of surf zone fish ecology, but comparatively little attention has been paid to spatial variability in the composition and abundance of surf zone fish assemblages. For many years, these habitats were labelled as 'harsh' and 'structurally homogeneous environments' and were thought to offer little in terms of habitat diversity, cover or productivity (Pearse et al. 1942, Hedgepeth 1957, Springer \& Woodburn 1960). Recent evidence suggests, however, that fluctuations in certain physical variables such as the degree of wave exposure, sediment particle size and turbidity have a strong influence on the relative abundance of certain species and may alter the composition and species richness of surf zone fish assemblages (Hillman et 
al. 1977, Blaber \& Blaber 1980, Tallmark \& Evans 1986, Romer 1990, Pihl \& van der Veer 1992). The occurrence of diatom plumes and detached macrophyte accumulations and the proximity of subtidal reefs, rocky jetties, estuarine habitats and seagrass beds, may all contribute significantly to spatial variability in surf zone fish abundance and community structure (Robertson \& Lenanton 1984, Romer \& McLachlan 1986, Peters \& Nelson 1987, Wright 1989, Romer 1990).

Studies on juvenile flatfish distribution patterns on sandy beaches in the northern hemisphere suggest that their distribution patterns are controlled primarily by food availability, exposure and habitat structure (Lockwood 1974, Ziljstra et al. 1982, Poxton \& Nasir 1985, Berghahn 1987, van der Veer et al. 1991, Pihl \& van der Veer 1992). Differences in dietary preferences also result in segregation between $0+$ juvenile plaice, which are concentrated in shallow $(<5 \mathrm{~m})$ waters, and larger $1+$ individuals, which prefer deeper waters (Lockwood 1974, Ziljstra et al. 1982)

Few researchers have sampled more than 1 or 2 localities simultaneously, and thus most of the information available is derived from the work of different authors, often using different equipment and methodologies. Comparisons have thus largely been limited to discussions concerning dominant taxa or families only, as it is well known that comparisons made between samples collected over different time periods, using different gear, or even by different researchers are fraught with problems (Ross 1983, Lasiak 1984a, Ben- nett 1989a, Pierce et al. 1990, Gibson et al. 1993, Lamberth et al. 1995). The aim of this study was thus to compile a comprehensive data set of surf zone fish samples collected simultaneously from a number of sites over an extended time period, using the same equipment, personnel and methodologies. Such a data base could be used to make a comprehensive assessment of the factors that influence variations in surf zone fish abundance and community structure. This paper documents the species composition, abundance and size structure of fish communities at 11 sandy and mixed shore sites covering a range of exposure levels in False Bay, South Africa. Data were averaged over a long period ( $2 \mathrm{yr}$ ) in order to get a clearer idea of the influence of between-site variations in wave exposure, turbidity and macrophyte abundance on spatial distribution patterns of surf zone fishes. Seasonal and interannual variations in these assemblages were also analysed, but form the subject of another manuscript (Clark et al. 1996, this issue).

\section{STUDY AREA}

False Bay $\left(34^{\circ} 04^{\prime}-34^{\circ} 23^{\prime} \mathrm{S}, 18^{\circ} 26^{\prime}-18^{\circ} 51^{\prime} \mathrm{E}\right)$, situated in the southwestern Cape (Fig. 1), experiences a Mediterranean-type climate (Schulze 1965) with cold wet winters and hot dry summers. It is the largest true bay in southern Africa, having a total surface area of $1082 \mathrm{~km}^{2}$ and a volume of $44.6 \mathrm{~km}^{3}$ (Spargo 1991).

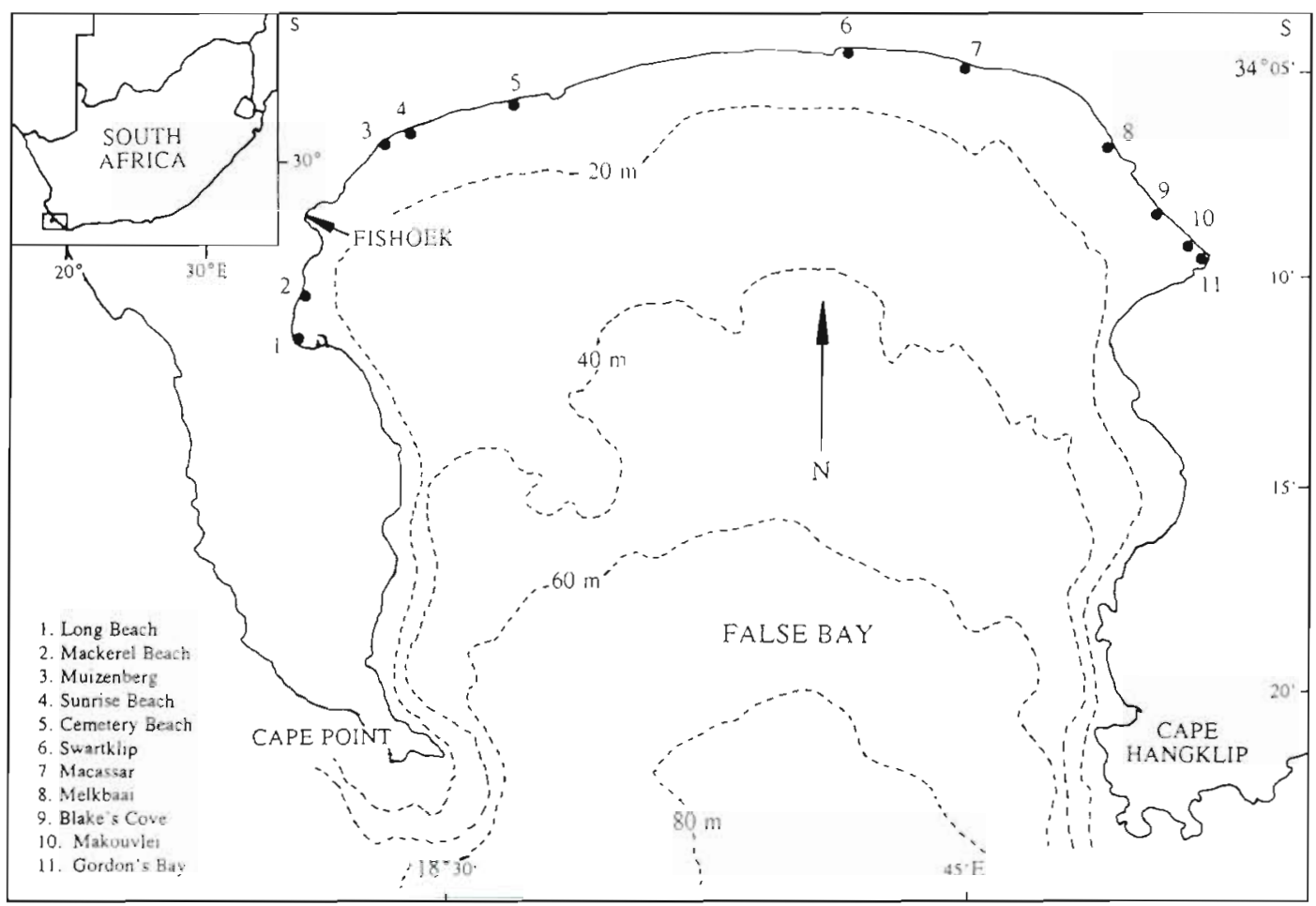

Fig. 1 The southwestern Cape (inset) and False Bay, South Africa, show ing location of the sampling sites and other features mentroned in the text 
Water depth is greatest in the mouth of the Bay (approximately $80 \mathrm{~m}$ ), which slopes up steeply towards the western and eastern coastlines which are dominated by rocky shores, while sloping gently up to the northern coastline which consists almost entirely of sandy beach. Tidal ranges in False Bay, as with most of the southern African coastline, are relatively modest compared with other parts of the world, and show a mean spring range of $1.48 \mathrm{~m}$ (Spargo 1991). Mean salinities in False Bay range from approximately 35.0 to $35.3 \%$, but may fall below $34.0 \%$ in the northeast corner in the winter months due to river discharge (Atkins 1970). Eleven collecting stations (Fig. 1), selected so as to encompass as wide a range of habitat types as possible, were established on the western, northern and northeastern shores of the Bay. These sites, encompassing both mixed shore and sandy beach environments of varying exposure levels, are described briefly below.

Sites 1 and 2 (Long Beach and Mackerel Beach) are situated in Simon's Bay, a small enclave on the western shore of False Bay. These sites have steep intertidal profiles, narrow surf zones and very clear waters. Located in the lee of the Simonstown Peninsula and the Simonstown harbour breakwater, Long Beach is well protected from prevailing swells and wave action was practically absent on most occasions. Intertidally, this site is made up of unbroken sand, and subtidally of sand together with a narrow kelp-covered reef running parallel to the shore on the extreme northern edge. Mackerel Beach, situated further to the north, receives considerably less protection from prevailing swells and, with its steeply shelving shore, is a moderately exposed beach, made up intertidally of isolated sandstone boulders interspersed with larger areas of sand.

Muizenberg and Sunrise (Sites 3 and 4), in the nor thwestern corner of False Bay, are both gently sloping, moderately exposed sandy beaches with broad surf zones. The shore in this area is made up entirely of unbroken sand terminating in rocky shoreline at the western border of the Muizenberg site. Surf phytoplankton accumulations (Anaulis biostratis) of varying intensity were observed on occasions at both sites.

Sites 5, 6 and 7 (Cemetery, Macassar Beach and Swartklip) are all highly exposed beaches situated on the northern shore directly opposite the mouth of the Bay. The former 2 sites consist entirely of unbroken sand and have steeply sloping intertidal profiles, broad surf zones and periodically well-developed rip currents with associated dense surf phytoplankton accumulations. Swartklip, lying adjacent to the Wolfgat Cliffs, is composed of low-lying, isolated rocky outcrops protruding from the sand in the moderately sloping sub-and intertidal parts of the shore.
The remaining 4 sites (Melkbaai, Makouvlei, Blake's Cove and Gordon's Bay) are situated in the northeastern corner of False Bay. Protection is derived from the gently shelving bottom (Fig. 1) and rocky outcrops running approximately parallel to, and 200 to $500 \mathrm{~m}$ distant from, the shore. These break up and dissipate incoming swells, ensuring that conditions are almost always calm. Melkbaai (Site 8 ) is the most exposed of these 4 sites, but is nonetheless a very gently sloping, sheltered sandy beach composed of fine sand. The shore at Blake's Cove is encircled on the seaward and western boundaries by rocky bars and by a slipway and wooden jetty on the eastern boundary, making it among the most sheltered areas in the Bay. Accumulations of detached aquatic macrophytes, prevalent in this area, were frequently netted in large quantities. Rooted aquatic macrophytes and macrofaunal burrows were also in evidence in the sandy bottom. The shore at Makouvlei (Site 10) is made up of irregularly laid, angular sedimentary rock outcrops, overlain in places by a layer of sand containing numerous macrofaunal burrows. Elongated sedimentary rock outcrops, directed offshore and interspersed with larger gently sloping sand (high shore) and cobble (low shore) bottom areas, make up the shore at Gordon's Bay (Site 11). Discharge from perennial rivers emptying into the northeastern corner of the Bay, coupled with poor water circulation in this area, ensures that high turbidities and low salinities prevail at the latter 4 sites for much of the year.

\section{MATERIALS AND METHODS}

Sampling methods. Samples were collected during daylight from each of the 11 sites (Fig. 1) around the perimeter of False Bay at approximately monthly intervals for 24 mo between July 1991 and June 1993. The apparatus used was a $30 \times 2 \mathrm{~m}, 12 \mathrm{~mm}$ stretched mesh beach-seine net fitted with a $2 \mathrm{~m}$ deep bag at its midpoint, and a weighted foot rope, to which two $30 \mathrm{~m}$ long ropes were attached. The net was laid parallel to the shore in water approximately $1.5 \mathrm{~m}$ deep, between 10 and $60 \mathrm{~m}$ offshore, and was hauled by 4 persons, one on each end of the net and one on each rope. Total area sampled was taken as the distance the net was laid offshore multiplied by the mean width of the haul.

All fish collected were identified to species and measured to the nearest $1 \mathrm{~mm}$ (total length), except where samples were very large, in which case measurements were restricted to a subsample of 200 individuals per species. Numbers of juvenile fish in each haul were estimated by calculating the number of individuals in each species smaller than the size at $50 \%$ maturity, as reported in the literature (Appendix 1). A visual 
assessment, based on macroscopic features, was made of the state of maturity of each fish for those species for which published information was not available. Turbidity of surf zone waters was measured in Formazin Turbidity Units (FTU) using a Hach DR/2000 spectrophotometer (where 1 FTU = 1 NTU when made with a nephalometer). Density of detached aquatic macrophytes at each site was calculated by dividing the total volume of seaweed in the net (l) by the total sampling area $\left(\mathrm{m}^{2}\right)$. Intertidal slope and median particle size were measured at quarterly intervals at each site and averaged over the 2 yr sampling period. Measurements of intertidal slope were made with transect poles, using the sea horizon as a levelling device. Median particle diameter was calculated by sieving sediments through a series of sieves graded at $0.5 \Phi$ intervals on a mechanical shaker. Maximum wave height was taken as the difference between crest and trough of the largest waves observed at the back of the surf line during each particular sampling interval. The composition of the shore at each site was rated subjectively and allocated a score $(\%)$ according to the proportion of rock on the shore within a $100 \times 50 \mathrm{~m}$ block, with the shorter axis extending from the spring high water mark seawards. These estimations were based on observations made in the field and on recent high resolution aerial photographs of the relevant sites. Approximate tidal heights were calculated for the time at which each sample was taken by extrapolation from tables of predicted hourly tidal heights published by the South African Navy Hydrographer.

Data analysis. For comparative purposes, it was necessary to transform all catch data into densities (no. fish $\mathrm{m}^{-2}$ ), as the total area swept by the net varied considerably between samples (from 150 to $900 \mathrm{~m}^{2}$ ). Data on the species composition and density of fish in the surf were compared using a variety of statistical procedures. Multivariate analyses of community structure were performed according to the strategy of Field et al. (1982), incorporating changes and additional procedures advocated by Clarke (1993) and Clarke \& Ainsworth (1993). Briefly, root-root transformed data were converted to triangular matrices of similarities between every pair of samples using the Bray-Curtis similarity coefficient. Similarities between samples were displayed on dendrograms and ordination plots, following the application of Multi-Dimensional Scaling (MDS). Biotic and abiotic similarity matrices (compiled in the same way using all possible combinations of environmental variables) were compared using weighted Spearman rank correlation coefficients $\left(\rho_{w}\right)$ in order to determine which subset of environmental yariables correlated best with spatial variations in biotic structure. Little concordance was evident between the biotic MDS ordination and ordinations of the most important environmental variables (the final step in this analysis advocated by Clarke \& Ainsworth 1993), even when the best possible combination selected by the model was used. These comparisons are not presented. Rather, plots of all environmental variables were overlaid on the biotic ordination after being scaled according to their magnitude, as originally advocated by Field et al. (1982). Species principally responsible for sample groupings formed by the Cluster and MDS analyses were identified using Simper analysis (Clarke 1993). These analyses were performed using the CLUSTER, MDS, BIOENV and SIMPER programs on the Primer computer package, version 4.0 (Plymouth Marine Laboratory, Plymouth, UK).

Stepwise multiple regression analyses were used to determine which suite of environmental factors was most influential in controlling the observed variation in fish density between sites. These computations were performed using the SYSTAT computer package (SYSTAT Inc., Evanston, IL, USA), whilst adhering to protocols laid down by Zar (1984) and Wilkinson (1990). Species richness was estimated using Margalef's index (d) (Margalef 1958), diversity $\left(H^{\prime}\right)$ using the Shannon index of diversity (Pielou 1969), evenness $(J)$ using Pielou's evenness index (Pielou 1969), and dominance (D) using Simpson's dominance index (Simpson 1949), all using $\log _{\mathrm{e}}$.

\section{RESULTS}

\section{Physical characteristics of the sampling sites}

Table 1 lists important physical variables recorded at each of the 11 sites during the $2 \mathrm{yr}$ sampling period. Mean maximum wave heights recorded at Long Beach, Blake's Cove, Makouvlei and Gordon's Bay were all less than $0.3 \mathrm{~m}$, with Long Beach exhibiting the lowest value $(0.11 \pm 0.01 \mathrm{~m})$. Intermediate values ( 0.6 to $0.9 \mathrm{~m}$ ) were recorded at Melkbaai, Muizenberg, Mackerel Beach and Sunrise. Highest values (>1 m) were recorded at Swartklip, Cemetery Beach and Macassar Beach, with the highest recorded mean maximum wave height $(1.26 \pm 0.07 \mathrm{~m})$ occurring at Cemetery Beach. Mean width of the surf zone at each of the sites ranged from 1.7 to $284.0 \mathrm{~m}$ (corresponding to Long Beach and Macassar Beach respectively). Greatest values ( $>195 \mathrm{~m}$ ) were recorded along the northern shore of the Bay (Muizenberg to Macassar Beach; Fig. 1). Lower values $(<100 \mathrm{~m})$ were recorded at the sites on the western and northeastern shores of the Bay. Mean intertidal slopes ranged from a maximum of 1:8 (Long Beach) to 1:48 (Melkbaai), while median particle size ranged from $0.20 \mathrm{~mm}$ (Melkbaai) to $0.71 \mathrm{~mm}$ (Cemetery Beach). Physical and biological variables 
Table 1. Physical environmental variables recorded at sampling sites in False Bay, South Africa. The variable 'Exposure' represents scores allocated to the sampling sites based on McLachlan's (1980) rating system, and 'Rock' the proportion of the shore occupied by rocky substratum. Where appropriate, values are listed as $\pm \mathrm{SE}$

\begin{tabular}{|c|c|c|c|c|c|c|c|c|c|}
\hline & $\begin{array}{l}\text { Wave } \\
\text { helght } \\
\text { (m) }\end{array}$ & $\begin{array}{l}\text { Surf zone } \\
\text { width } \\
\text { (m) }\end{array}$ & $\begin{array}{l}\text { Intertidal } \\
\text { slope }\end{array}$ & $\begin{array}{l}\text { Median } \\
\text { particle } \\
\text { size }(\mathrm{mm})\end{array}$ & Exposure & $\begin{array}{c}\text { Temperature } \\
\left({ }^{\circ} \mathrm{C}\right)\end{array}$ & $\begin{array}{l}\text { Turbidity } \\
\text { (FTU) }\end{array}$ & $\begin{array}{l}\text { Macrophyte } \\
\text { abundance } \\
\left(1 \mathrm{~m}^{-2}\right)\end{array}$ & $\begin{array}{l}\text { Rock } \\
(\%)\end{array}$ \\
\hline Long Beach & $0.11 \pm 0.01$ & $1.7 \pm 0.4$ & $1: 8$ & 0.43 & 7.0 & $16.8 \pm 0.7$ & $0.3 \pm 0.1$ & $0.074 \pm 0.009$ & 1 \\
\hline Mackerel & $0.91 \pm 0.06$ & $16.5 \pm 22.7$ & $1: 10$ & 0.40 & 14.0 & $16.7 \pm 0.7$ & $0.8 \pm 0.5$ & $0.013 \pm 0.001$ & 27 \\
\hline Muizenberg & $0.87 \pm 0.07$ & $251.3 \pm 50.6$ & $1: 31$ & 0.31 & 13.0 & $17.3 \pm 0.7$ & $2.3 \pm 0.5$ & $0.004 \pm 0.002$ & 8 \\
\hline Sunrise & $0.90 \pm 0.06$ & $232.5 \pm 36.3$ & $1: 27$ & 0.36 & 13.5 & $17.2 \pm 0.7$ & $4.6 \pm 1.1$ & $0.006 \pm 0.003$ & 0 \\
\hline Cemetery & $1.26 \pm 0.07$ & $195.0 \pm 35.0$ & $1: 13$ & 0.71 & 17.0 & $17.3 \pm 0.7$ & $5.1 \pm 0.9$ & $0.007 \pm 0.002$ & 0 \\
\hline Swartklıp & $1.15 \pm 0.07$ & $207.1 \pm 61.1$ & $1: 20$ & 0.31 & 14.5 & $17.3 \pm 0.8$ & $5.2 \pm 2.2$ & $0.008 \pm 0.001$ & 35 \\
\hline Macassar & $1.17 \pm 0.06$ & $284.0 \pm 54.9$ & $1: 16$ & 0.49 & 16.0 & $17.2 \pm 0.7$ & $3.9 \pm 0.5$ & $0.002 \pm 0.000$ & 0 \\
\hline Melkbaai & $0.64 \pm 0.07$ & $96.9 \pm 26.5$ & 1.48 & 0.20 & 9.0 & $18.0 \pm 0.8$ & $5.4 \pm 0.9$ & $0.013 \pm 0.011$ & 0 \\
\hline Blake's Cove & $0.23 \pm 0.04$ & $8.8 \pm 1.9$ & $1: 11$ & 0.28 & 4.0 & $18.2 \pm 0.9$ & $8.6 \pm 1.1$ & $0.678 \pm 0.265$ & 54 \\
\hline Makouvlei & $0.18 \pm 0.04$ & $47.5 \pm 18.7$ & $1: 17$ & 0.30 & 6.0 & $18.4 \pm 0.9$ & $8.4 \pm 1.5$ & $0.150 \pm 0.058$ & 69 \\
\hline Gordon's Bay & $0.29 \pm 0.06$ & $66.6 \pm 28.0$ & $1: 19$ & 0.24 & 6.5 & $18.1 \pm 0.9$ & $12.7 \pm 2.0$ & $0.082 \pm 0.040$ & 63 \\
\hline
\end{tabular}

relating to wave action, sediment particle diameter, intertidal slope, depth of reduced layers and the presence or absence of macrofaunal burrows at each site were entered into a rating scheme developed by McLachlan (1980) which assesses the degree of exposure of sandy beaches on a scale of 0 to 20 . These scores, listed in Table 1, ranged between 4 and 17. Lowest scores ( 4 to 7 ) were attributed to Blake's Cove. Makouvlei, Gordon's Bay and Long Beach, intermediate scores (13 to 14.5) to Muizenberg, Mackerel Beach, Sunrise and Swartklip, while Macassar Beach (16) and Cemetery Beach (17) received the highest scores. A strong positive correlation was evident between mean wave heights recorded at all sites and exposure score ( $\mathrm{r}=0.95, \mathrm{p}<0.001$ ).

A gradient in overall mean water temperature was evident across the study sites. Mean temperatures were lowest on the western shore of the Bay (Long Beach: $16.8 \pm 0.7^{\circ} \mathrm{C}$; Mackerel Beach: $16.7 \pm 0.7^{\circ} \mathrm{C}$ ), but increased marginally along the northern shore (17.2 to $17.3^{\circ} \mathrm{C}$ ) to the northeastern corner of the Bay, where mean temperatures were all greater than $18^{\circ} \mathrm{C}$. Mean turbidities on the western shore of the Bay (Long Beach and Mackerel Beach) were both less than 1 FTU, with Long Beach exhibiting the lowest value 0.3 \pm 0.1 FTU). Surf zone waters along most of the northern shore of the Bay (Muizenberg to Melkbaai) displayed intermediate turbidities of 2.2 to $5.4 \mathrm{FTU}$, while mean values at the remaining 3 sites (Blake's Cove to Gordon's Bay) in the northeastern corner were the highest recorded $(8.6$ to 12.7$)$. The mean density of detached aquatic macrophytes ranged from 0.002 to $0.678 \mathrm{I} \mathrm{m}^{-2}$ (Table 1). Lowest densities $\left(<0.01 \mathrm{l} \mathrm{m}^{-2}\right)$ were recorded along the northern shore of the Bay between Muizenberg and Macassar Beach. Long Beach, Mackerel Beach, Melkbaai and Gordon's Bay exhibited intermediate densities $\left(0.01\right.$ to $\left.0.09 \mathrm{l} \mathrm{m}^{-2}\right)$, while the greatest concentrations were found at Makouvlei $\left(0.150 \pm 0.0581 \mathrm{~m}^{-2}\right)$ and Blake's Cove $(0.678 \pm$ $0.265 \mathrm{l} \mathrm{m}^{-2}$ ). Macrophyte abundance was negatively correlated with both mean wave height $(\mathrm{r}=0.54, \mathrm{df}=$ 9 ) and exposure $(r=0.68, \mathrm{df}=9)$. The amount of rock on the shore at each site ranged from $0 \%$ (Sunrise, Cemetery Beach, Macassar Beach and Melkbaai) up to a maximum of $69 \%$ (Makouvlei). Gordon's Bay (63\%), Blake's Cove (54\%), Swartklip (35\%) and Mackerel Beach $(27 \%)$ received high scores, while Long Beach and Muizenberg were both rated at less than $10 \%$.

\section{Fish fauna}

A total of 68610 fish from 45 species representing 26 families were collected in 264 beach-seine hauls made at 11 collecting stations in False Bay during the 24 mo period, July 1991 to June 1993 (Table 2). Atherina breviceps, Liza richardsonii and Rhabdosargus globiceps were the 3 most abundant species at all sites, where they provided between 69 and $99 \%$ of the total numbers of fish captured. Amblyrhynchotes honkenii was the only other species recorded at all 11 sites. In terms of numbers, the fewest fish (742) were captured at Swartklip, while the greatest number (17436) was captured at Makouvlei. Total areas netted at each of the sampling sites differed considerably (Table 2), primarily as a result of differences in intertidal profile and the composition of the shore at each site. Sampling areas ranged between 17900 and $4575 \mathrm{~m}^{2}$. Total area sampled was greatest $\left(>14000 \mathrm{~m}^{2}\right.$ ) at the more sheltered, gently sloping sandy beach sites such as Melkbai and Muizenberg, but was considerably smaller $(<10000)$ at the more steeply sloping 
Table 2. Density (1nd. $100 \mathrm{~m}^{-2}$ ) and community parameters associated with ichthyofaunal assemblages sampled by beach-seining at 11 sites in False Bay, South Africa

\begin{tabular}{|c|c|c|c|c|c|c|c|c|c|c|c|c|c|}
\hline & $\begin{array}{l}\text { Long } \\
\text { Beach }\end{array}$ & $\begin{array}{c}\text { Mackerel } \\
\text { Beach }\end{array}$ & $\begin{array}{l}\text { Muizen- } \\
\text { berg }\end{array}$ & $\begin{array}{l}\text { Sunrise } \\
\text { Beach }\end{array}$ & $\begin{array}{l}\text { Cemetery } \\
\text { Beach }\end{array}$ & $\begin{array}{c}\text { Swart- } \\
\text { klip }\end{array}$ & $\begin{array}{c}\text { Macassar } \\
\text { Beach }\end{array}$ & $\begin{array}{l}\text { Melk- } \\
\text { baai }\end{array}$ & $\begin{array}{l}\text { Blake's } \\
\text { Cove }\end{array}$ & $\begin{array}{c}\text { Makou- } \\
\text { vlei }\end{array}$ & $\begin{array}{c}\text { Gordon's } \\
\text { Bay }\end{array}$ & $\begin{array}{c}\text { All s } \\
\text { Density }\end{array}$ & $\begin{array}{l}\text { tes } \\
\text { No. of ind. }\end{array}$ \\
\hline Atherina breviceps & 0.65 & 31.28 & 15.04 & 8.39 & 10.86 & 039 & 4.45 & 11.24 & 30.45 & 116.20 & 43.81 & 30.89 & 37023 \\
\hline Liza richardsonif & 44.12 & 7.15 & 24.42 & 17.01 & 1412 & 4.66 & 23.16 & 1779 & 63.40 & 6623 & 17.41 & 20.42 & 24474 \\
\hline Rhábdosargus globiceps & 7.58 & 0.15 & 2.72 & 2.66 & 1.60 & 0.13 & 0.32 & 2.02 & 6.36 & 123 & 5.57 & 2.20 & 2641 \\
\hline Diplodus sargus & 0.39 & 0.12 & 041 & & 0.02 & 0.23 & & 0.01 & 2.28 & 2.26 & 2.66 & 0.58 & 696 \\
\hline Gilchristella aestuaria & & & 0.13 & 0.33 & 0.15 & 0.14 & 0.03 & 0.10 & 0.73 & 0.26 & 14.27 & 0.56 & 674 \\
\hline Psammogobius knysnaensis & 0.27 & & 0.01 & 0.01 & 0.01 & & & 0.04 & 2.18 & 2.87 & 2.65 & 050 & 600 \\
\hline Pomatomus saltatrix & & 0.14 & 1.82 & 0.56 & 0.06 & 013 & 0.60 & 0.31 & 0.57 & 8.11 & 0.17 & 0.49 & 582 \\
\hline Sarpa salpa & & & & & & 0.02 & & & 0.05 & 0.01 & 5.50 & 0.41 & 488 \\
\hline Amblyrhynchotes honkenu & 0.06 & 0.04 & 0.14 & 0.02 & 0.06 & 0.02 & 0.11 & 0.04 & 0.85 & 0.51 & 0.54 & 0.18 & 220 \\
\hline Liza lricuspidens & & & 0.01 & & & & 0.07 & & 1.25 & 0.20 & 0.26 & 0.11 & 137 \\
\hline Liza dumerliti & & & 0.02 & & & & 0.01 & 0.01 & 0.98 & 0.42 & 0.03 & 0.08 & 97 \\
\hline Rhinobatos annulatus & & & 0.62 & 0.03 & & & 0.03 & 0.02 & & 0.04 & 0.16 & 0.08 & 91 \\
\hline Umbrina canariensis & 0.04 & 0.02 & 0.01 & & 0.01 & 0.34 & 0.08 & 0.23 & 0.18 & 0.02 & 0.08 & 0.08 & 93 \\
\hline Caffrogobius nudiceps & 0.01 & & & & & & & 0.01 & 0.43 & 0.11 & 0.56 & 007 & 82 \\
\hline Mugil cephalus & & & & 0.01 & & & 003 & 0.04 & 0.05 & 0.17 & 032 & 0.06 & 66 \\
\hline Clinus supercilhosus & 0.06 & 0.02 & & & & & & & 0.41 & 0.08 & 0.18 & 0.05 & 58 \\
\hline Lithognathus lithognathus & & & 004 & 0.03 & 0.02 & 0.09 & 0.01 & 0.08 & 048 & 0.04 & 0.01 & 0.05 & 62 \\
\hline Lichia amia & & & & & 0.01 & & & 0.13 & 0.17 & 0.03 & 0.15 & 004 & 45 \\
\hline Heteromycterus capensis & 0.84 & 0.02 & & & & & & 0.01 & 1.35 & 0.16 & 1.85 & 0.03 & 320 \\
\hline Solea bleeker & & & 0.01 & & 0.01 & & & 0.01 & 0.38 & & 0.03 & 0.03 & 30 \\
\hline Chelidonichthyes capensis & 0.14 & 0.01 & 0.02 & 0.01 & & & & 0.04 & 0.11 & & & 0.02 & 24 \\
\hline Dichistius capensis & & & 0.01 & & & 0.18 & 0.01 & & & & & 0.01 & 15 \\
\hline Lithognathus mormyrus & 0.18 & 0.01 & 0.01 & & & & & & & & & 0.01 & 15 \\
\hline Clinus latipennis & & 0.05 & & 0.03 & 0.01 & 0.01 & & & & & 0.04 & 001 & 13 \\
\hline Cancelloxus longior & 0.12 & & & & & & & & & & & 0.01 & 9 \\
\hline Rhabdosargus holubi & & & & & & & & & & 0.01 & 0.08 & 0.01 & 8 \\
\hline Myliobatis aquila & & & 0.02 & & & & & & 0.06 & & 0.02 & 0.01 & 7 \\
\hline Coryphaena hippurus & & & 0.02 & 0.03 & & & & & & & & $<0.005$ & 3 \\
\hline Dasyatis crysonota & & & & & & & & & 0.03 & & 0.01 & $<0.005$ & 3 \\
\hline Syngnathus acus & 0.01 & 0.02 & & & & & & & & & & $<0.005$ & 2 \\
\hline Calfrogobius caffer & 0.01 & 0.02 & & & & & & & & & 0.05 & $<0.005$ & 4 \\
\hline Diplodus cervinus & & & & & & & & & 0.02 & & & $<0.005$ & 2 \\
\hline Gonorhynchus gonorhynchus & 0.01 & & & & & & & & & & & $<0.005$ & 1 \\
\hline Trachinocephalus myops & 0.03 & & & & & & & & & & & $<0.005$ & 2 \\
\hline Dichistius mullifasciatus & 0.01 & & & & & & & & & & & $<0.005$ & 1 \\
\hline Trachurus trachurus & & & & & 0.01 & & & & & & & $<0.005$ & $i$ \\
\hline Trachinotus botla & & & & & & & 0.01 & & & & & $<0.005$ & $i$ \\
\hline Trachinotus africanus & & & & & & & & 0.01 & & & & $<0.005$ & 1 \\
\hline Engraulis japonicus & & & & & & & & & & & 0.01 & $<0.005$ & $i$ \\
\hline Heniochus acummatus & & & & & & & & & & & 0.01 & $<0.005$ & 1 \\
\hline Monodactylus falciformes & & & & & & & & & & 0.01 & & $<0.005$ & 1 \\
\hline Haploblepharus edwarsii & & & & & & & & & & & 0.01 & $<0005$ & 1 \\
\hline Sphyraena acutipinnis & & & & & & & & & & & 0.01 & $<0.005$ & 1 \\
\hline Triakis megalopterus & & & & & & & & & & & 0.01 & $<0.005$ & 1 \\
\hline Fucomimus mus & & & & & & & & & & & 0.01 & $<0.005$ & 1 \\
\hline All species & 54.53 & 39.02 & 45,43 & 29.11 & 26.92 & 6.32 & 28.93 & 32.14 & 112.78 & 198.97 & 96.48 & 57.25 & \\
\hline No. of individuals & 4828 & 11765 & 5109 & 3073 & 2775 & 742 & 3126 & 3903 & 7255 & 17436 & 8903 & 68610 & \\
\hline Total no. of species & 17 & 13 & 18 & 13 & 14 & 12 & 14 & 19 & 23 & 21 & 31 & 45 & \\
\hline Richness & 1.89 & 1.28 & 1.99 & 1.49 & 1.64 & 1.66 & 1.62 & 2.18 & 2.47 & 2.05 & 3.30 & 3.95 & \\
\hline Diversity & 0.64 & 0.25 & 1.15 & 108 & 0.95 & 0.81 & 0.61 & 102 & 1.42 & 073 & 1.55 & 1.17 & \\
\hline Evenness & 0.22 & 0.10 & 0.40 & 042 & 0.36 & 0.33 & 0.23 & 0.35 & 0.45 & 024 & 0.45 & 0.31 & \\
\hline Dominance & 0.71 & 0.89 & 0.41 & 0.42 & 0.45 & 0.69 & 0.72 & 0.45 & 0.37 & 0.64 & 0.35 & 0.42 & \\
\hline Mean nelting area $\left(\mathrm{m}^{2}\right)$ & 186 & 254 & 656 & 624 & 453 & 343 & 463 & 746 & 347 & 362 & 618 & 4.54 & \\
\hline Total netting area $\left(\mathrm{m}^{2}\right)$ & 4575 & 5850 & 15750 & 14975 & 9975 & 8225 & 11100 & 17900 & 8325 & 8335 & 14825 & 119835 & \\
\hline
\end{tabular}


sandy/mixed-shore sites such as Long Beach, Mackerel Beach and Swartklip.

Makouvlei and Swartklip contained the greatest (199.0 fish $100 \mathrm{~m}^{-2}$ ) and the lowest ( 6.3 fish $100 \mathrm{~m}^{-2}$ ) densities of fish respectively. High densities were also recorded at Blake's Cove (112.8 fish $\left.100 \mathrm{~m}^{-2}\right)$ and Gordon's Bay $\left(96.8\right.$ fish $\left.100 \mathrm{~m}^{-2}\right)$, whereas intermediate densities (26 to 55 fish $100 \mathrm{~m}^{-2}$ ) were recorded at the remaining 7 sites. In terms of numbers of species recorded, Gordon's Bay represented the richest site with over 31 species present, while Swartklip was the poorest with only 12 species. Numbers of species recorded at Blake's Cove and Makouvlei were also high (>20), while the remaining sites were represented by 13 to 19 species each. Community parameters (Margalef's species richness, Shannon diversity, Pielou's evenness and Simpson's dominance) associated with the fish communities sampled at each of the sites are also listed in Table 2. Species richness was considerably greater at Gordon's Bay (3.3) than at any of the other sites. Makouvlei, Melkbaai and Blake's Cove displayed intermediate values (2.05 to 2.47 ), while the remaining sites received low scores ( 1.28 to 1.89). Species diversity was highest at Gordon's Bay (1.55) and Blake's Cove (1.42), lowest $(0.25)$ at Mackerel Beach and intermediate $(0.61$ to 1.15$)$ at the remaining sites. Evenness ranged from 0.10 to 0.45 , with greatest values at Gordon's Bay and Blake's Cove (0.45 for both) while Mackerel Beach again registered the lowest value. Greatest dominance was recorded at Mackerel Beach (0.89), while Macassar, Long Beach, Swartklip and Makouvlei also displayed high values (0.64 to 0.72$)$. Lowest levels of dominance were recorded at Gordon's Bay (0.35) and Blake's Cove $(0.37)$. Intermediate levels $(0.41$ to 0.45$)$ were recorded at the remaining sites. Values of species richness, diversity, evenness and dominance for catches for all sites combined were $3.95,1.17,0.31$ and 0.42 respectively

Numbers of juvenile fish exceeded adults at all sites, except Mackerel Beach and Gordon's Bay, where they provided 6 and $38 \%$ of the totals respectively. Overall, numbers of juvenile fish exceeded those of adult fish, making up just over half $(52.9 \%)$ of the total catch, with $23(51 \%)$ of the species being represented by immature individuals only, $18(40 \%)$ as both adults and juvenile and only $4(9 \%)$ as adults only (Appendix 1). Teleost fish (40 species), comprising 98.7 to $100 \%$ of the catches, far outnumbered elas- mobranchs ( 5 species, 0 to $1.3 \%$ of the catches) at all sites. The majority of the fish captured were small individuals (Appendix 1), only $1.4 \%$ of which exceeded $200 \mathrm{~mm}$ TL (total length). No individuals captured during this survey were greater than $1 \mathrm{~m}$ in length. Length frequency distributions of the 10 most abundant species are illustrated in Fig. 2

Faunal similarities among sites were analysed using root-root transformed density data using Cluster and MDS analyses. Cluster analysis separated the 11 sampling sites into 2 major groups which linked at the $62 \%$ level of similarity. The first group, composed of 7 sites, was made up of Swartklip, Mackerel Beach, Macassar Beach, Muizenberg, Sunrise, Cemetery Beach, and Melkbaai. The remaining 4 sites, Blake's Cove, Makouvlei, Gordon's Bay and Long Beach, made up the second group. At higher levels of similarity (80 to $90 \%$ ), 2 closely linked groups of samples and a number

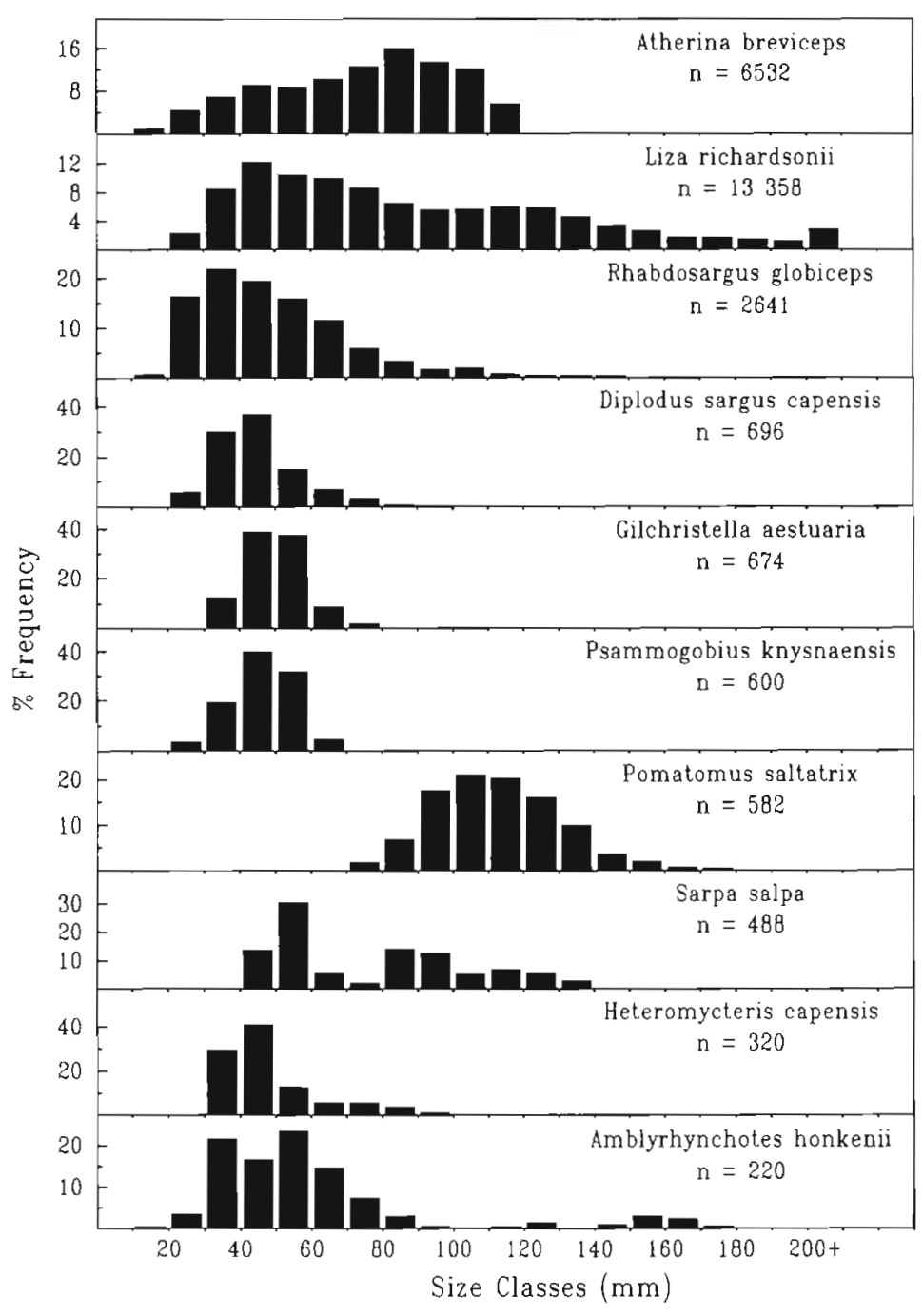

Fig. 2. Size frequency distributions of the 10 most abundant fish species captured in beach-seine hauls from the False Bay surf zone 
of outliers were evident (Fig. 3). Macassar Beach, Muizenberg, Sunrise, Cemetery Beach and Melkbaai were linked together in a group, as were Blake's Cove, Makouvlei and Gordon's Bay, while Swartklip, Mackerel Beach and Long Beach remained unattached. Separation of the sampling sites in the ordination plot derived from the MDS analysis corresponded almost exactly to the pattern generated by the Cluster analysis. Sites linking together between the 80 and $90 \%$ levels of similarity clustered together in the MDS plot, while the 3 outlying samples were placed at some distance from these groups, albeit on the same side of the plot as the groups to which they were linked in the cluster analysis.

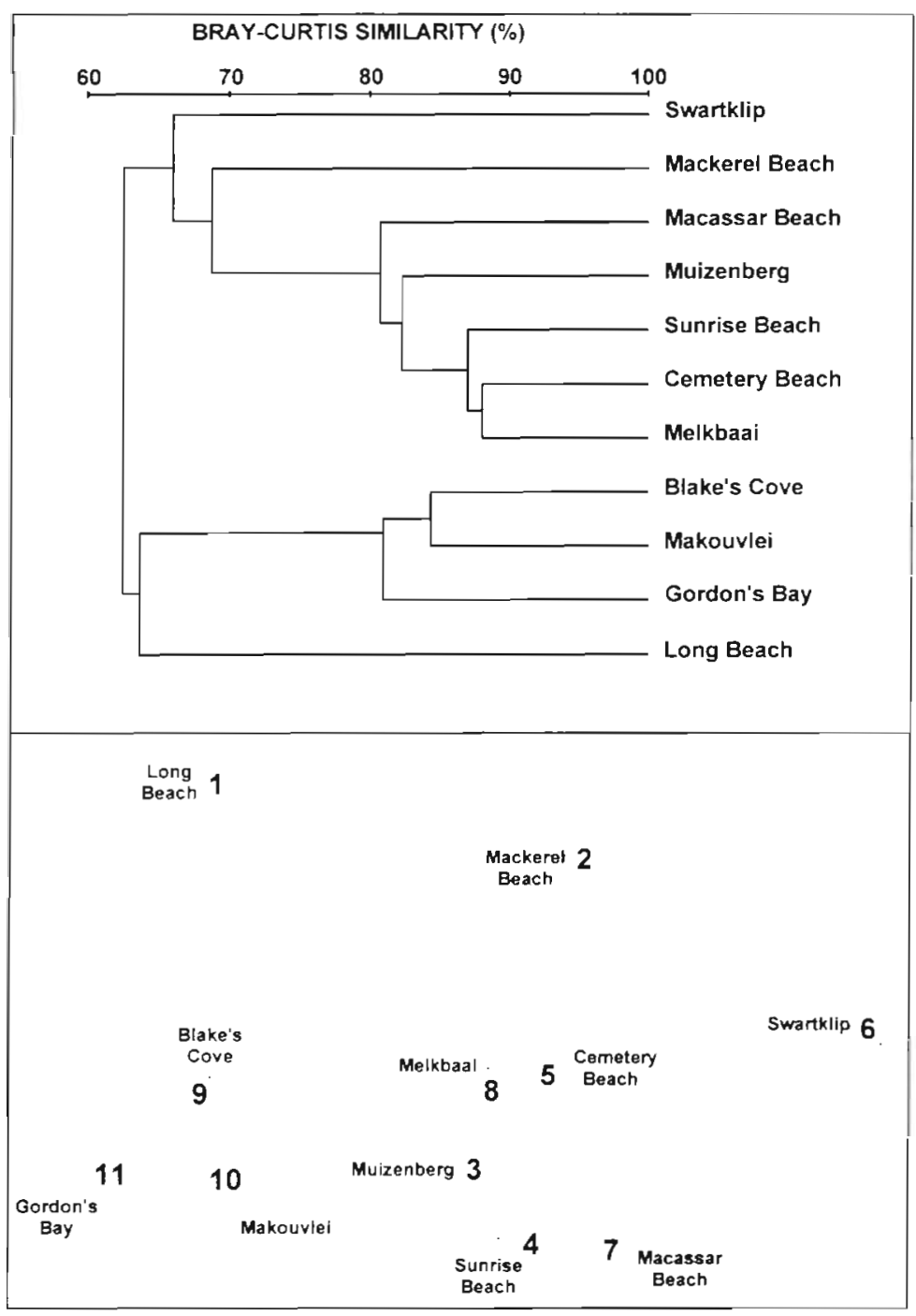

Fig. 3. Dendrogram and MDS ordination showing similarities between sites based on the composition and abundance of fish species in seine net hauls made in the surf zone of False Bay. Groups of species delineated at the $80 \%$ level in the dendrogram are circled in the ordination plot. Stress for MDS plot $=0.07$
Differences in species abundance patterns across the sampling sites were examined using Cluster and MDS analyses and by examining the contributions of the more abundant species to dissimilarities between groups of sites identified earlier (Fig. 3), using Simper analysis. A reasonably close match was evident between sample groupings in the dendrogram and ordination plot (Fig. 4) despite the high stress loading (0.14) on the latter. Four groups and 2 outlying samples were evident in these 2 diagrams. From Table 2, it is evident that species in Groups A and B ( 7 and 5 species respectively), were captured predominantly at Sites 9 to 11 (Blake's Cove, Makouvlei and Gordon's Bay). Species in Group C (4 species) were captured in varying numbers at all sites, while those in Group D ( 2 species), recorded in low densities at a number of sites, were recorded in by far their greatest densities at Gordon's Bay, where $>90 \%$ of these individuals were captured. Table 3 shows the results of breaking dissimilarities between the sites in Group 1 (Fig. 3; Blake's Cove, Makouvlei, Gordon's Bay) and 2 (Muizenberg, Sunrise, Cemetery Beach, Macassar Beach and Melkbaai) into the individual components provided by the top 10 species. Together these species accounted for $>55 \%$ of the dissimilarity between these 2 groups of samples. Most (7) of these species came from Groups A and B above, while both species from Group D and one from Group C were also present.

\section{Multivariate analyses of relations between biotic and environmental variables}

A total of 8 physical environmental variables - mean wave height, mean width of the surf zone, amount of rock in the netting area (rock), water temperature, intertidal slope, median particle size, detached macrophyte abundance and turbidity were used for multivariate analyses. These data were employed in 2 different ways. In the first instance, values for all 8 variables (as detailed in Table 2) were entered directly into the multivariate models. The models were then rerun, but all variables pertaining to the relative exposure of the sites (wave height, surf zone width, intertidal slope, and median particle size) were replaced with 'exposure scores' generated using McLachlan's (1980) rating scheme, as detailed in the previous section (Table 2 ). 
Results from the BIOENV procedure yielded rank correlation coefficients $\left(\rho_{w}\right)$ of 0.63 and 0.52 for the full and reduced sets of environmental variables respectively. Wave height, rock and turbidity were selected as the combination of variables best able to predict spatial variations in community structure in the first instance, and the variables exposure, rock and turbidity in the second. Stepwise multiple regression analyses performed using the 2 sets of environmental variables selected rock and wave height for the former, and rock and exposure for the latter, as the best predictors of spatial variations in surf zone fish density. Coefficients of determination $\left(\mathrm{r}^{2}{ }_{a \mathrm{~d}_{j}} \cdot\right.$, the adjusted multiple coefficient of determination) generated by these 2 models were 68.4 and $62.7 \%$ respectively.

When plots of all environmental variables, scaled according to their magnitude, were overlaid on the biotic ordination of the 11 sites (Fig. 5a), it was immediately clear why the variables incorporated in the final BIOENV models were in fact selected (Fig 5b-j). The variable wave height and exposure separated not only the 2 groups of closely linked sites formed by the MDS analysis, but also split all sites clearly into 2 groups corresponding to those formed in the higher levels of the cluster diagram (Fig. 3). Amount of rock on the shore (Fig. 5d) and turbidity (Fig. 5e) differentiated clearly between the 2 groups of samples formed by the MDS analysis, but not between the 3 outlying samples. Although it was not selected by any of the multivariate models, macrophyte abundance (Fig. 5f) split the samples in a similar way to wave height and exposure. Little concordance was evident between the scaling of the remaining environmental variables (surf zone width, intertidal slope, median particle size and water temperature; Fig. $5 g-j$ ) and biotic similarities evident between sites (Fig. 5a).

\section{DISCUSSION}

Marked differences were evident between the fish assemblages recorded at the 11 sites studied during this survey. Mean density of fish, for example, varied by a factor of $>30$ between sites, while the number of

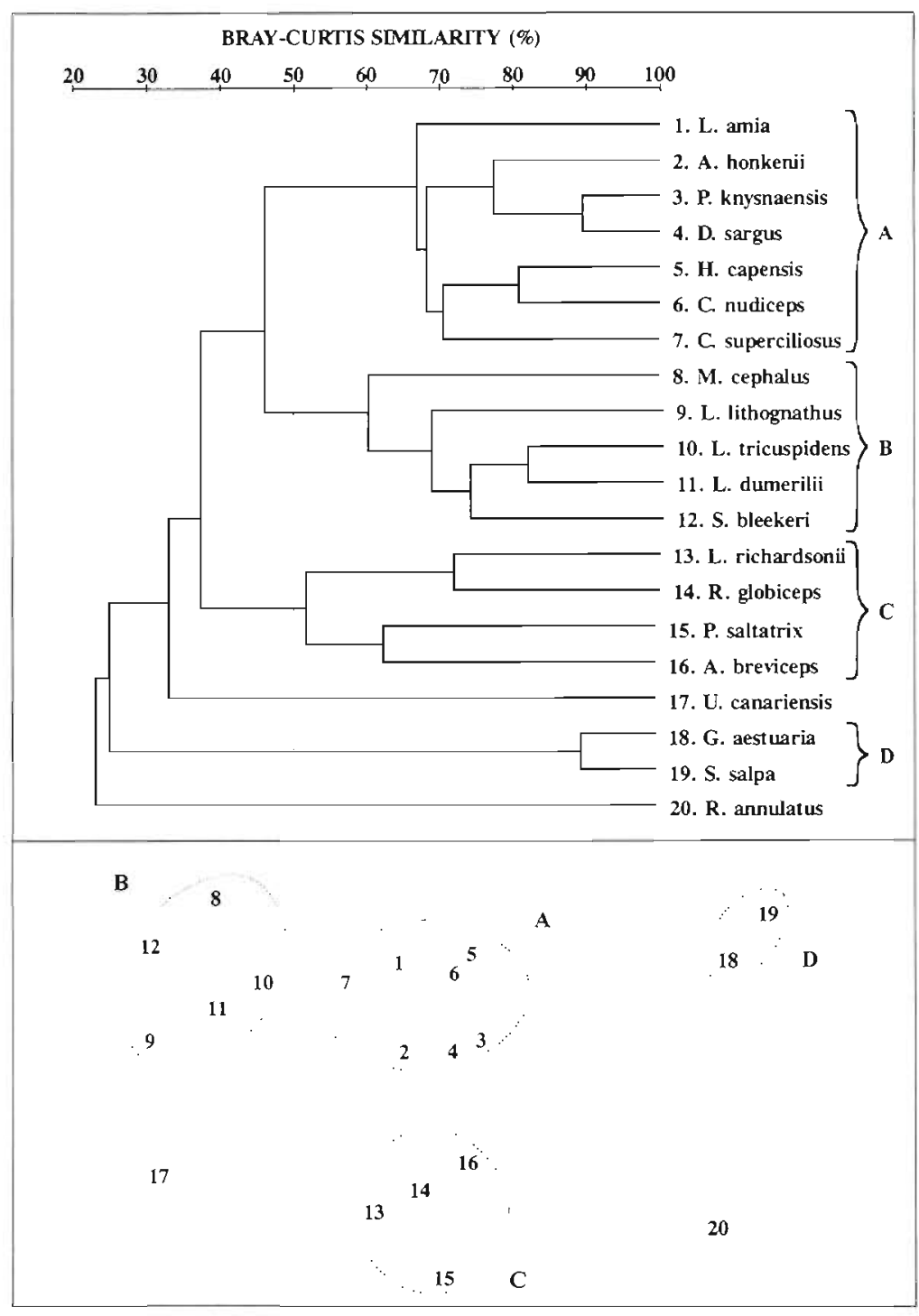

Fig. 4. Dendrogram and MDS ordination showing similarities between species based on their occurrence at 11 localities in the False Bay surf zone. Groups of species delineated at the $50 \%$ level in the dendrogram are circled in the ordination plot. Stress for MDS plot $=0.13$. Full genus names are given in Table 2

species recorded at some sites was more than double that at others. Although factors such as water clarity, nature of the substratum, temperature, wave exposure and macrophyte abundance are all thought to influence the capture efficiency of beach seine nets (Hunter \& Wisby 1964, Lyons 1986, Pierce et al. 1990, Romer 1990, Lamberth et al. 1995), we believe that in the case of this study these influences were probably minimal. Capture efficiency may have been reduced under conditions of heavy surf or low turbidity, when the net was lifted over rocky obstacles or when large quantities of macrophytes were netted, but extra care was taken during these periods, so as to ensure that this did not 
Table 3. Breakdown of average dissimilarity between Sites $9-11$ and Sites $3-5+7-8$ into contributions of the 10 top specles, listed in order of decreasing contribution. $\delta$, is the average contribution of the $i$ th species to the dissimilarity between the 2 groups, $\delta, / S D\left(\delta_{1}\right)$ the ratio between average contribution of the $i$ th species $\left(\delta_{1}\right)$ and the standard deviation of the $\delta$ values for that species $\left[\operatorname{SD}\left(\delta_{1}\right)\right]$ and Cum $\delta_{j} \%$ the cumulative contribution to the total dissimilarity, rescaled as a percentage

\begin{tabular}{|lcccc|}
\hline Species & $\delta_{i}$ & $\delta_{1} / \mathrm{SD}\left(\delta_{1}\right)$ & $\delta_{i} \%$ & Cum $\delta_{i} \%$ \\
\hline Atherina breviceps & 3.09 & 1.88 & 7.21 & 7.21 \\
Psammogobıus knysnaensis & 3.05 & 4.87 & 7.12 & 14.32 \\
Diplodus sargus & 2.95 & 2.87 & 6.89 & 21.21 \\
Heteromycterus capensis & 2.72 & 3.73 & 6.35 & 27.56 \\
Sarpa salpa & 2.30 & 1.53 & 5.36 & 32.92 \\
Caffrogobius nudiceps & 2.09 & 4.07 & 4.88 & 37.81 \\
Clinus superciliosus & 2.02 & 6.38 & 4.71 & 42.52 \\
Liza tricuspidens & 1.99 & 2.26 & 4.64 & 47.15 \\
Gilchristella aestuaria & 1.76 & 1.13 & 4.11 & 51.27 \\
Liza dumerilii & 1.73 & 1.76 & 4.03 & 55.29 \\
\hline
\end{tabular}

happen. Problems of this nature were also minimised by adjusting the hauling area accordingly or aborting the haul if it was considered to be inefficient. Averaging of monthly data over a 2 yr period and using fourthroot-transformed density data for multivariate analyses are also likely to have increased the robustness of the data set. Thus, differences in the physical make-up or physical characteristics of these sites must, to a large extent, be responsible for these differences, as these sites are all located in close proximity to one another (less than $40 \mathrm{~km}$ apart) within False Bay. These sites were made up of varying combinations of physical characteristics, however, with few gradients extending uniformly across more than 1 or 2 sites, which makes it very difficult to determine which are the most important contributory factors. The influences of a selection of these variables will therefore first be discussed individually before attempting to draw general conclusions.

\section{Exposure}

Wave action, thought by many authors to be synonymous with exposure, is considered to be one of the major factors controlling physical and chemical characteristics of the surf zone environment (Eltringham 1971, Eleftheriou \& Nicholson 1975, McLachlan 1980). This variable exerts a considerable influence on the composition, community structure and zonation of benthic invertebrate assemblages (McLachlan et al. 1984, Morin et al. 1985, Dexter 1990). Blaber \& Blaber (1980) found that juveniles of certain fish species inhabiting inshore waters of the Indo-Pacific occurred

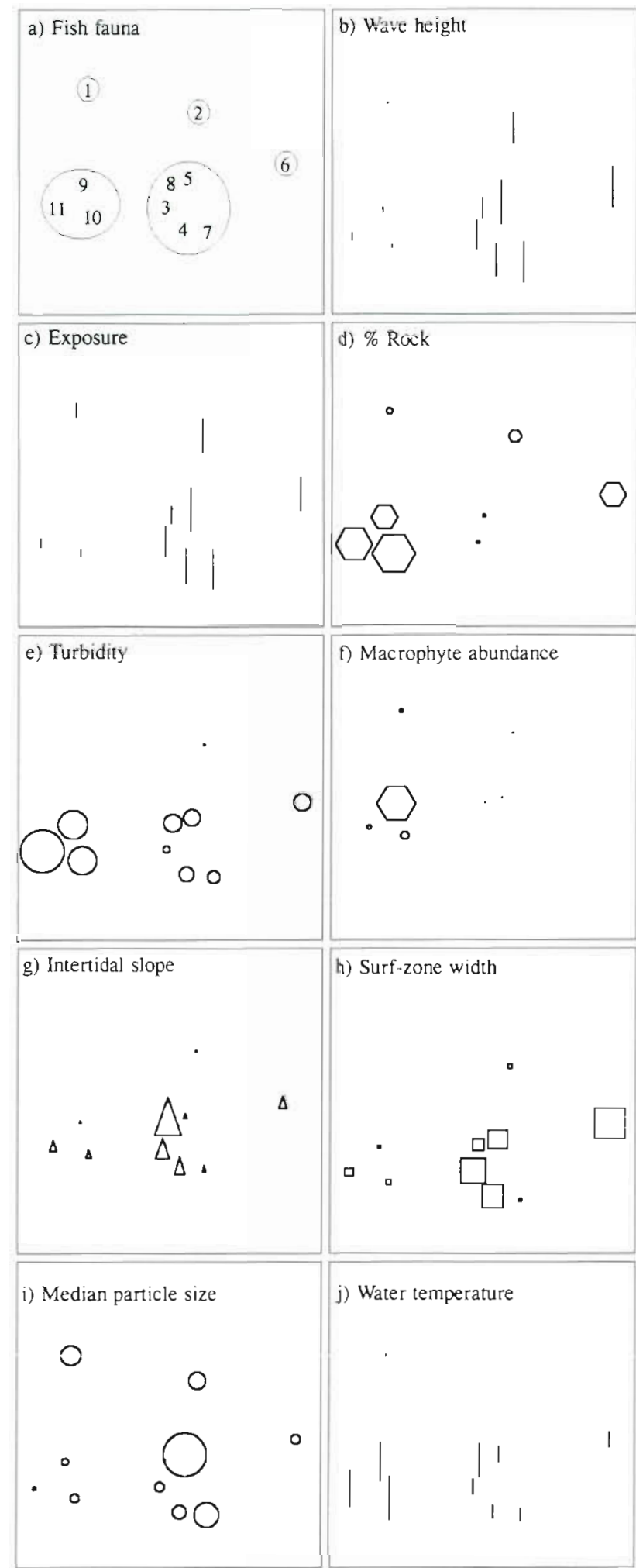

Fig. 5. Relation of site similarities, based on ichthyofaunal composition (a), to a variety of environmental variables. [The numbers in (a) represent Sites 1 to 11.J Objects representing the environmental variables in each case were scaled according to their relative magnitudes and superimposed on the biotic plot (b to ) 
only in calm, non-turbulent areas, while this variable appeared to have no influence on the other species Romer (1990) compared surf zone fish assemblages at 3 localities spanning an exposure gradient in Algoa Bay, South Africa, and found that as exposure increased, fish abundance (catch rate) and diversity declined, while the degree of dominance increased.

The influence of exposure on the fish communities sampled during this study was examined using both the mean wave height at all sites and the rating system developed by McLachlan (1980), which incorporates variables such as wave height, surf zone width, intertidal slope and median particle size. Mean wave height and exposure were greatest at sites situated along the northern shore, directly opposite the mouth of the Bay. According to McLachlan's (1980) rating system, these sites were considered to be exposed to very exposed. Mean wave height tailed off rapidly on approaching the northeastern corner of the Bay, where all sites were rated as sheltered, but less rapidly along the western shore, due to the presence of more steeply shelving bottoms which did little to dissipate incoming waves Abundance of fish in the surf, and community parameters, showed a strong positive response to gradients in both mean wave height and exposure. However, these were only general trends, and the greatest density of fish was not recorded at the most sheltered sites, nor was the lowest density recorded at the most exposed site. Similarly, peaks in the numbers of species recorded, species richness, diversity and evenness did not coincide with the sites with lowest wave action or exposure, despite showing a general decline with increasing exposure. In contrast to Romer's (1990) findings, the degree of dominance recorded for the fish communities at the various sites did not increase with increasing exposure. High and low levels of dominance were recorded at both sheltered and exposed sites. When either mean wave height or exposure was entered into multivariate analyses examining the influence of all physical variables on spatial variations in community structure and fish density in the surf, it was included in the final set of variables that were best able to predict biotic variability. Models incorporating mean wave height had coefficients of determination that were marginally higher than those incorporating exposure in both cases. A high degree of concordance was evident between the scaling of these 2 variables and the biotic ordination plots upon which they were overlaid (Fig. 5).

\section{Rock}

Despite their prevalence, shores composed of mixed rock and sand have been extremely poorly studied.
Only 3 publications (Bally et al. 1984, McQuaid \& Dower 1990, Brown et al. 1991) deal specifically with invertebrate communities inhabiting these areas in southern Africa, and studies of such communities in other areas are equally sparse (e.g. Taylor \& Littler 1982, Littler et al. 1983). Some authors have recorded the presence of reef fishes in surf zone habitats (e.g Anderson et al. 1977, Futch \& Dwinell 1977), whereas others have suggested that the proximity of rocky reefs may influence the composition of assemblages under study (e.g. Romer 1990, Gibson et al. 1993). Hillman et al. (1977) sampled fish assemblages at 6 surf zone localities in Long Island Sound with substrata composed of varying amounts of emergent rock, but provided little discussion on the differences between these assemblages. Differences observed between the numbers of individuals and fish species collected from surf zone habitats immediately adjacent to rock jetties and those further ( $>1 \mathrm{~km}$ ) away led Peters \& Nelson (1987) to conclude that the additional habitat diversity provided by these structures significantly enhances the species richness of fish assemblages inhabiting surf zone environments.

The proportion of the substrata at the 11 sampling sites composed of emergent rock ranged between 0 ( 3 sites) and $69 \%$. However, few unequivocal patterns in abundance or structure between the various fish assemblages were evident. Fish abundance and numbers of species were greatest at the 3 sites containing the largest proportion of rock $(>50 \%)$, but little structure could be distinguished in these variables at the remaining sites, except that those sites containing no rock had intermediate to low fish densities. Considerable differences were, however, evident when comparisons were drawn between the biota at comparable sites, situated in close proximity, but with (e.g. Muizenberg) or without (Sunrise) rocky substrata. Fish abundance, number of species, species richness and diversity were all higher at Muizenberg, which is situated immediately adjacent to rocky coastline, than at Sunrise, which is bound on either side by extensive sandy beaches. Multivariate models employed to select the combination of variables best able to predict spatial variations in fish density and community structure all contained the variable rock. When this variable was overlaid on the biotic ordination (Fig. 5), variations in amount of rock clearly distinguished between the 2 groups of sites formed by the MDS analysis.

\section{Turbidity}

Much attention has been focused on the influence of turbidity on the distribution patterns of fish in inshore waters, chiefly estuarine systems in southern Africa 
(Blaber \& Cyrus 1983, Cyrus 1983, Bruton 1985, Cyrus \& Blaber 1987a, b, c, 1992) and Australia (Blaber \& Blaber 1980, Cyrus \& Blaber 1982, Blaber et al. 1985, Weng 1990). It is thought to be the single most important factor influencing estuarine fish distribution patterns, as it provides cover for juveniles through a reduction in light intensity, which obscures prey species from visually orientating predators such as piscivorous fish and birds (Blaber \& Blaber 1980, Blaber 1981, Cyrus 1983, Cyrus \& Blaber 1987a, b). Some authors have suggested that higher invertebrate densities found in turbid areas may also attract some species to turbid waters, while others believe that turbidity may act as an important environmental cue, guiding fish into estuarine habitats (Blaber \& Blaber 1980 , Cyrus 1983). Fewer studies concerning the influence of turbidity on fish abundance have been undertaken in the marine environment and the influence of turbidity on distribution patterns in the marine environment is less well known. Blaber et al. (1985) attributed low numbers of fish recorded in mangrove and open shore habitats in western Australia to low turbidities in this area, and Ross et al. (1987) found that fish abundance in a surf zone habitat in the Gulf of Mexico was lowest during periods of clear water that occurred in conjunction with diminished wave activity. From data collected during their study of sheltered inshore marine environments in western Australia, Blaber \& Blaber (1980) concluded that although the presence of shallow water was the only common denominator sought by juveniles of most fish species, turbidity was probably the single most important factor influencing the distribution of species within these shallow water habitats. Although all turbidities recorded during this study fell within the clear to partially turbid category (<50 NTU) of Cyrus \& Blaber (1987a), this variable did appear to exert a strong influence on fish distribution patterns in False Bay.

Based on water clarity, the section of False Bay studied during this survey can be divided into 3 regions. Turbidities were generally low on the western side of the Bay, intermediate at sites across the northern shore and high in the northeastern corner. Discolouration of nearshore waters in the northern part of False Bay appears as milky green colour fronts to the naked eye and zones of high radiance on satellite images (Shannon et al. 1991). Shannon et al. (1991) found that this discolouration extends right through the water column, and divided these phenomena into 4 spatial categories: those prevalent in the northeastern and northwestern corners of the Bay, a narrower zone, and a tongue-like off-shore extension prevalent along the northern shore of the Bay. They found that discolouration was most prevalent in the northeastern corner of the Bay $140 \%$ of all occasions), and attributed it to a combination of high primary production from localised upwelling and nutrient cycling within a semi-permanent eddy in this sector of the Bay and to the recirculation of suspended material within this eddy. They attributed the remaining 3 features to a process whereby winds circulate organically rich material lifted by wave action in the middle of the Bay in a westerly direction along the northern shoreline. Silt-laden freshwater discharged from 4 perennial estuaries emptying into the northeastern corner of the Bay probably also contributes to the high turbidities found there, while the diminished wave action, lack of estuarine input and close proximity of deep water on the western shore result in clearer waters at the 2 sites in this area. Once again, few general patterns are evident in the spatial distribution of fish sampled during this survey with respect to this variable. Abundance and numbers of species captured were greatest at sites in the northeastern corner of the Bay, where turbidities were highest ( $>8$ FTU). Highest values for species richness, diversity and turbidity all coincided at Gordon's Bay, while dominance was greatest at sites where turbidity was lowest (Long Beach and Mackerel Beach), indicating that most species avoid very clear waters, as other authors (e.g. Blaber et al. 1985, Ross et al. 1987) have noted. Results of the multivariate analyses suggested that turbidity is a good predictor of spatial variations in surf zone fish community structure as a whole, but not of abundance alone. When overlaid on the biotic MDS plot of the 11 sites, it was clear that this variable played an important role in discriminating between the 2 major groups of sites (Fig. 5a, e) but not the 3 outlying sites.

\section{Detached macrophyte abundance}

After becoming detached from rocky substrata under the influence of storms or heavy wave action, macrophytes accumulate in the surf zones of sandy beaches in many parts of the world (ZoBell 1971, Cowper 1978, Robertson \& Lenanton 1984, Hull 1987, van der Merwe \& McLachlan 1987, Wright 1989). These accumulations are thought to contribute to the quality of the surf zone habitat for colonization by juvenile fishes through the protection they provide from piscivorous birds and fish and by the provision of additional food sources, both directly and indirectly through the detritus food chain (Lenantor et al. 1982, Robertson \& Lenanton 1984, Lenanton \& Caputi 1989, Wright 1989). In some areas, as much as $25 \%$ of the total coastal primary production is thought to pass through the surf zone of sandy beaches in the form of detached macrophyte detritus (Robertson \& Hansen 1982).

Volumes of aquatic macrophytes recorded at most of the sampling localities in this study were negligible 
$\left(\bar{x}<0.1 \mathrm{l} \mathrm{m}^{-2}\right)$, except for the 4 most sheltered sites (Long Beach, Gordon's Bay, Makouvlei and Blake's Cove), where average values of up to $0.7 \mathrm{l} \mathrm{m}^{-2}$ were recorded. Maximum values recorded at these sites 10.8 to $8.0 \mathrm{l} \mathrm{m}^{-2}$ ) correspond closely with those calculated by Robertson \& Lenanton (1984) (9.58 l m $\mathrm{m}^{-2}$ ) and Lenanton \& Caputi (1989) (1.73 $\left.1 \mathrm{~m}^{-2}\right)$, both of which noted a positive correlation between algal volumes and numbers of fish captured. Indeed, Robertson \& Lenanton (1984) found that fish abundance may be up to 10 times greater in weed patches than in areas of open sand. It is surprising therefore that, despite large differences between macrophyte abundance at sites on the left and right hand sides of the biotic ordination plot (Fig. 5a, h), this variable did not contribute significantly to spatial variations in fish abundance or community structure. However, this variable was significantly negatively correlated with both mean wave height and exposure, and thus the addition of macrophyte abundance to any of the multivariate models generated during this analysis would not have improved the fit of the models. The high degree of colinearity that exists between macrophyte abundance, exposure and wave height results in the model selecting that variable with the highest partial correlation coefficient only (in this case wave height). Wright (1989) found no correlation between algal volumes and fish abundance off sandy beaches in Sulaibikhat Bay, Kuwait, but maximum volumes of weed in this area were very much lower than those recorded here, and did not exceed $0.031 \mathrm{~m}^{-2}$

\section{Other variables}

Studies on 0-group flatfish distribution patterns on European beaches have shown that fish densities are usually greatest in areas where fine to intermediately sized sands predominate and least in exposed areas where sediments are coarser (Riley \& Holford 1965, Poxton \& Nasir 1985, Dorel et al. 1991, Pihl \& van der Veer 1992). This is believed to be related to the inability of the smaller fish to bury themselves in coarse sediments and hence take advantage of reduced drag forces induced by bottom currents, lower predation levels and potentially reduced metabolic rates (Riley \& Holford 1965, Berghahn 1986, Gibson \& Robb 1992, Pihl \& van der Veer 1992, Ansell \& Gibson 1993). Differences in sediment composition have also been shown to influence the distribution patterns of gobiid fish, also as a result of predator related mortalities (Evans \& Tallmark 1984, 1985, Tallmark \& Evans 1986). Variations in median particle size are closely linked to exposure and intertidal slope, as median particle size increases with exposure, whereas intertidal slope usually increases with increasing particle size while decreasing with increasing exposure (Davies 1972, Eleftheriou \& Nicholson 1975, McLachlan 1980). Thus, although variations in particle size may influence fish distribution patterns significantly on sheltered beaches in Europe, their effects are probably limited to benthic-dwelling or -feeding species on the very much more exposed beaches in South Africa, as their influence is probably overshadowed for the most part by exposure itself.

Likewise, we thought that surf zone width was unlikely to play a large role in structuring surf zone fish assemblages, apart from influencing the amount of available cover provided by turbulence and foam generated by breaking waves. Variation in mean water temperature, on the other hand, is known to exert a strong influence on seasonal variations in surf zone fish abundance (Gunter 1958, McFarland 1963, Anderson et al. 1977), and may have influenced the structure of surf zone fish populations in this study. Although the variations in mean water temperatures were not great $\left(<2^{\circ} \mathrm{C}\right)$, higher temperatures prevalent at the sites in the northeastern corner of the Bay probably contributed to the greater abundance of fish in this area.

While salinity was not monitored during this survey, this may also have exerted some influence on fish distribution patterns within the surf zone of False Bay. Salinity is considered to be one of the most important variables controlling fish distribution patterns in estuaries, as the ability to cope with fluctuations in the variable is the most essential adaptation by fish penetrating these environments (Pannikkar 1960, Whitfield et al. 1981). Indeed, fishes frequenting estuaries around the world are generally classified on the basis of their origin and salinity tolerances (e.g. Gunter 1945, McHugh 1967, Wallace et al. 1984, Claridge et al. 1986). Atkins (1970) noted that lowered salinities (<34 ppt) are sometimes prevalent in the northeastern corner of False Bay due to river discharge, particularly during winter Brief observations made during this survey indicate that lowered salinities occur at the sampling sites in this area considerably more frequently than Atkins suggests, usually in conjunction with highly turbid waters. On one occasion (23 June 1992) a number of live amphibian tadpoles were captured in a haul made at Gordon's Bay together with a good catch of fish. Turbidity on this occasion was 46 FTU, the highest recorded. When present, water with lowered salinity is likely to be particularly attractive to estuarine opportunistic and/or dependent species, as the energetic costs of osmoregulation are reduced in salinities below that of seawater (Potter et al. 1990).

It is apparent from the foregoing discussion that many factors influence spatial variations in surf zone 
fish community structure in False Bay. Although the 3 variables selected most frequently by multivariate analyses (exposure, presence of rock on the shore and turbidity) are probably primarily responsible for the variability observed, no factor acts in isolation and variations in some of the other physical variables (e.g. abundance of detached macrophytes, salinity and temperature) almost certainly also play a role. Some variables also interact in a complex manner. For example, the amount of rock may have a positive influence on fish abundance at sheltered or moderately exposed sites (e.g. Makouvlei or Gordon's Bay vs Long Beach and Muizenberg vs Sunrise), but not at more exposed sites (e.g. Swartklip vs Macassar Beach). By examining variations in the abundance of some of the more common species over different combinations of these abiotic variables it is also possible to identify groups of species based on habitat associations. For example, by comparing assemblages across shelter-exposure and sand-rock gradients, 3 groups of species can be identified. Four species (Liza richardsonii, Atherina breviceps, Rhabdosargus globiceps and Pomatomus saltatrix) were present in varying numbers under all combinations of these variables. Psammogobius knysnaensis and Heteromycteris capensis appear to be indifferent to the presence of rock on the shore, but seem to prefer sheltered areas, whereas Sarpa salpa, found only in association with rocky substrata, appears to be indifferent to variations in exposure. Juvenile galjoen Dichistius capensis, although recorded in small numbers, were found exclusively at exposed sites composed of mixed rock and sand. Despite being one of southern Africa's premier angling species (Penrith \& Loutit 1982, Bennett 1988), only 3 juveniles of the size range recorded during this survey (33 to $175 \mathrm{~mm}$; Appendix 1) have previously been recorded in the marine environment (van der Lingen 1994), probably as such habitats have never been properly sampled.

Finally, it is instructive to examine the way in which the more common species were grouped based on their occurrence at the various sampling localities, using multivariate analyses (Fig. 4). One group (Group C) contained seemingly ubiquitous species identified earlier as being indifferent to variations in exposure and the amount of rock on the shore. Another group (Group B) contained species found almost exclusively at sites in the northeastern corner of the Bay. These species have all been classified as entirely or largely dependent on estuaries as juveniles (Wallace et al. 1984), and therefore may have been attracted to the low salinities and high turbidities prevalent in this area. A third group (Group A), composed of 7 species, were found predominantly at sheltered sites, and form a 'calm water group'. Thus species in. Group $\mathrm{C}$ can be seen as a 'core' group present at all sites, to which a variety of other species are added, depending on the particular suite of environmental conditions prevailing

\section{CONCLUSIONS}

Results of this study indicate that 3 factors, namely the degree of wave exposure, the presence of emergent rock on the shore and turbidity, are the most important factors controlling spatial variations in surf zone fish abundance and community structure in False Bay. Certain other variables, e.g. abundance of detached macrophytes, salinity and temperature, also play a role, but are probably of secondary importance Species-specific preferences for varying combinations of these variables result in variations in the structure and overall abundance of fish assemblages in different areas. This study clearly demonstrates the value of simultaneously studying the influence of a whole suite of environmental variables on fish community structure as it allows the relative importance of a variety of these factors to be assessed relative to one another. Subsequently isolating and analyzing changes in surf zone fish abundance and community structure over gradients of a single variable allows the influence of the more important factors identified in this study to be explored in more detail.

Acknowledgements. We thank all staff and students of the Zoology Department at the University of Cape Town who helped with the netting surveys and with the processing of the data. We thank Prof. C. L. Griffiths and all those who commented on earlier drafts of this manuscript. This work was funded by the South African Nature Foundation (affiliated to the World Wildlife Fund for Nature) and the Sea Fishery Fund, the latter through a contract with the Sea Fishery Research Institute, South Africa.

\section{LITERATURE CITED}

Anderson WD Jr, Dias JK, Dias RK, Cupka DM, Chamberlain NA (1977) The macrofauna of the surf zone off Folly Beach, South Carolina. NOAA Tech Rep NMFS SSRF-704

Ansell AD, Gibson RN (1993) The effect of sand and light on predation of juvenile plaice (Pleuronectes platessa) by fishes and crustaceans. J Fish Biol 43:837-845

Armstrong MJ, Thomas RM (1989) Clupeoids. In: Payne AIL, Crawford RJM (eds) Oceans of life off southern Africa. Vlaeberg, Cape Town, p 105-121

Atkins GR (1970) Thermal structure and salinity of False Bay. Trans R Soc S Afr 34:11-128

Bally R, McQuaid CD, Brown AC (1984) Shores of mixed sand and rock: an unexplored marine ecosystem. S Afr J Sci 80: 500-503

Beckley LE (1984) The ichthyofauna of the Sundays Estuary. South Africa, with particular reference to the juvenile marine component. Estuaries 7:248-258

Bennett BA (1988) Some considerations for the management 
Appendix 1. Numbers of individuals, length ranges (total length, TL) and sizes at maturity of fish captured in beach-seine hauls made at 11 sites in False Bay between July 1991 and June 1993. SL: standard length; FL: fork length

\begin{tabular}{|c|c|c|c|c|c|}
\hline & & $\mathrm{n}$ & $\begin{array}{l}\text { Size } \\
\text { range }\end{array}$ & $\begin{array}{l}\text { Size at } \\
\text { maturity }\end{array}$ & $\%$ immature \\
\hline \multicolumn{6}{|l|}{ Osteichthyes } \\
\hline Atherinidae & Atherna breviceps & 37023 & $16-129$ & $43^{\circ}$ & 14.1 \\
\hline \multirow[t]{5}{*}{ Carangidae } & Luchia amia & 45 & $46-380$ & $600^{h}$ & 100.0 \\
\hline & Trachinotus africanus & 1 & 98 & & 100.0 \\
\hline & Trachinotus bolla & 1 & 56 & & 100.0 \\
\hline & Trachurus trachurus & 1 & 67 & $200^{c}$ & 100.0 \\
\hline & Unidentified & 8 & $22-37$ & & \\
\hline Chaetodontidae & Heniochus acuminatus & 1 & 42 & & 100.0 \\
\hline \multirow[t]{4}{*}{ Clinidae } & Cancelloxus longior & 9 & $71-125$ & & 0.0 \\
\hline & Clinus latipennis & 13 & $40-131$ & $45^{d}$ & 23.1 \\
\hline & Clinus superciliosus & 58 & $38-151$ & $65^{\circ}$ & 13.8 \\
\hline & Fucomimus mus & 1 & 95 & & \\
\hline Clupeidae & Gilchristella aestuaria & 674 & $30-86$ & $34^{n}$ & 0.7 \\
\hline Coryphaenidae & Coryphaena hippurus & 3 & $43-47$ & & \\
\hline \multirow[t]{2}{*}{ Dichistiidae } & Dichistius capensis & 15 & $33-175$ & $310^{1}$ & 100.0 \\
\hline & Dichistius multifasciatis & 1 & 30 & $210^{b}$ & 100.0 \\
\hline Engraulidae & Engraulis japonicus & 1 & 95 & $90^{9}$ & 0.0 \\
\hline \multirow[t]{3}{*}{ Gobuidae } & Caffrogobius caffer & 4 & $56-93$ & $55^{\circ}$ & 0.0 \\
\hline & Caffrogobius nudiceps & 82 & $28-108$ & $65^{h}$ & 28.7 \\
\hline & Psammogobius knysnaensis & 600 & $22-71$ & $37^{d}$ & 12.7 \\
\hline Gonorynchidae & Gonorhynchus gonorhynchus & 1 & 181 & & 0.0 \\
\hline Monodactylidae & Monodactylis falciformis & 1 & 40 & $170^{k}$ & 100.0 \\
\hline \multirow[t]{4}{*}{ Mugilidae } & Liza dumerilii & 97 & $53-181$ & $200^{\prime}$ & 100.0 \\
\hline & Liza richardsondi & 24474 & $20-402$ & $230^{\prime}$ & 97.9 \\
\hline & Liza tricuspidens & 137 & $78-290$ & $400^{1}$ & 100.0 \\
\hline & Mugil cephalus & 66 & $100-420$ & $450^{\mathrm{e}}$ & 100.0 \\
\hline Pomatomidae & Pomatomus saltatrix & 582 & $73-256$ & $240^{1}$ & 99.8 \\
\hline Sciaenidae & Umbrina canariensis & 93 & $27-635$ & $300^{4}$ & 75.5 \\
\hline \multirow[t]{2}{*}{ Soleıdae } & Heteromycteris capensis & 320 & $33-121$ & $45^{151}$ & 48.5 \\
\hline & Solea bleekeri & 30 & $39-190$ & $100^{\prime}$ & 62.5 \\
\hline \multirow[t]{7}{*}{ Sparidae } & Dilpodus cervinus hottentotus & 2 & $52-76$ & $334^{n}$ & 100.0 \\
\hline & Diplodus sargus capensis & 696 & $22-220$ & $180^{r}$ & 99.7 \\
\hline & Lithognathus lithognathus & 62 & $74-810$ & $650^{\circ}$ & 98.3 \\
\hline & Lithognathus mormyrus & 15 & $42-131$ & 190 & 100.0 \\
\hline & Rhabdosargus globiceps & 2641 & $16-172$ & $260^{9}$ & 100.0 \\
\hline & Rhabdosargus holubi & 8 & $42-218$ & $180^{\mathrm{e}}$ & 75.0 \\
\hline & Sarpa salpa & 488 & $42-142$ & $180^{r}$ & 100.0 \\
\hline Sphyraenidae & Sphyraena acutipinnis & 1 & 64 & & 100.0 \\
\hline Syngnathidae & Syngnathus acus & 2 & $92-178$ & $125^{\star \prime}$ & 50.0 \\
\hline Synodontidae & Trachinocephalus myops & 2 & $55-80$ & & 100.0 \\
\hline Tetraodontidae & Amblyrhynchotes honkenis & 220 & $18-178$ & $80^{\mathrm{e}}$ & 87.9 \\
\hline Triglidae & Chelidonichthyes capensis & 24 & $29-85$ & $305^{s}$ & 100.0 \\
\hline Unidentified & & 4 & $22-37$ & & \\
\hline \multicolumn{6}{|l|}{ Chondrichthyes } \\
\hline Carcharhinidae & Triakis megalopterus & 1 & 440 & $1400^{\prime}$ & 100.0 \\
\hline Dasyatidae & Dasyatis crysonota & 3 & $225-385$ & $500^{u}$ & 100.0 \\
\hline Myliobatidae & Myliobatis aquila & 7 & $290-780$ & $540^{v}$ & 71.4 \\
\hline Rhinobatidae & Rhinobatos annulatus & 91 & $223-910$ & $700^{\prime \prime}$ & 71.1 \\
\hline Scyliorhinidae & Haploblepharus edwarsii & 1 & 240 & $410^{\prime}$ & 100.0 \\
\hline \multicolumn{2}{|l|}{ Total } & 68610 & & & 52.9 \\
\hline \multicolumn{6}{|c|}{ 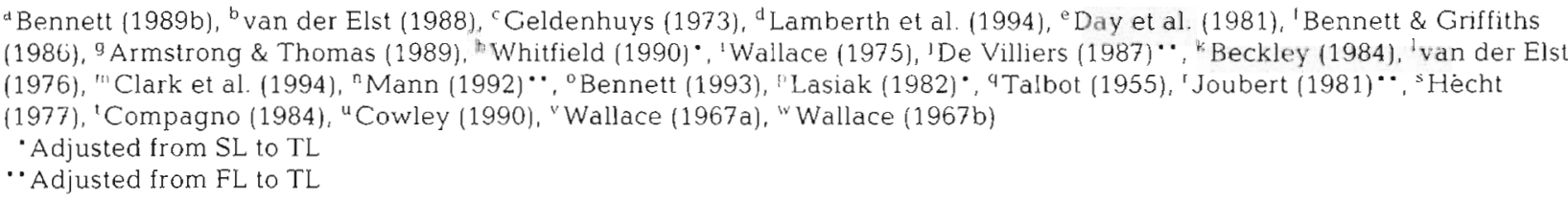 } \\
\hline
\end{tabular}


in South Africa of the galjoen Coracinus capensis (Cuvier), an important shore angling species off the southwestern Cape. S Afr J mar Sci 6:133-142

Bennett BA (1989a) Fish community of a moderately exposed beach on the southwestern Cape coast of South Africa and an assessment of this habitat as a nursery for juvenile fish. Estuar coast Shelf Sci 28:293--305

Bennett BA (1989b) A comparison of the fish communities in nearby permanently open, seasonally open and normally closed estuaries in the southwestern Cape, South. Africa. S Afr J mar Scl 8:43-55

Bennett BA (1993) Aspects of the brology and life history of the white steenbras Lithognathus lithognathus in southern Africa. S Afr J mar Sci 13:83-96

Bennett BA, Griftiths CL (1986) Aspects of the biology of galjoen Coracinus capensis (Cuvier) off the south-western Cape, South Atrica. S Afr J mar Sci 4:153-162

Berghahn R (1986) Determining abundance, distribution and mortality of 0-group plaice (Pleuronectes platessa L.) in the Wadden Sea. J appl Iththyol 2:11-22

Berghahn R (1987) The Wadden Sea as a nursery for fish and crustacean species. In: Tougard S, Asbirk S (eds) Proc 5th Int Wadden Sea Symp. National Forest and Nature Agency, Esbjerg, p 69-85

Blaber SJM (1981) The zoogeographic affinities of estuarine fishes in south-east Africa. S Afr J Sci 77:305-307

Blaber SJM, Blaber TG (1980) Factors affecting the distribution and abundance of juvenile estuarine and inshore fish. J Fish Biol 17:143-162

Blaber SJM. Cyrus DP (1983) The biology of Carangidae (Teleostei) in Natal estuaries. J Fish Biol 17:143-162

Blaber SJM, Young JW, Dunning MC (1985) Community structure and zoogeographic affinities of the coastal fishes of the Dampier region of north-western Australia. Aust J mar Freshwat Res 36:247-266

Brown AC, Wynberg RP, Harris SA (1991) Ecology of shores of mixed rock and sand in False Bay. Trans R Soc S Afr 47 : $563-574$

Bruton MN (1985) The effects of suspensoids on fish. Hydrobiologia 125:221-241

Claridge PN, Potter IC, Hardisky MW (1986) Seasonal changes in movements, abundance and diversity of fish fauna of the Severn Estuary. J mar biol Ass UK 66:229--258

Clark BM, Bennett BA, Lamberth SJ (1994) A comparison of the ichthyofauna of two estuaries and their adjacent surfzones, with an assessment of the effects of beach-seining on the nursery function of estuaries for fish. S Afr J mar Sci 14:121-131

Clark BM, Bennett BA, Lamberth SJ (1996) Temporal variations in surf zone fish assemblages from False Bay, South Africa. Mar Ecol Prog Ser 131:35-47

Clarke KR (1993) Non-parametnc multivariate analyses of changes in community structure. Aust if Ecol 18:117-143

Clarke KR, Ainsworth M (1993) A method of linking multivariate community structure to environmental variables. Mar Ecol Prog Ser 92:205-219

Compagno LJV (1984) FAO species catalogue, Vol 4, Sharks of the world. An annotated and illustrated cailalogue of shark species known to date, Part 1, Hexanchiformes to Lamniformes. FAO Fish Synopsis No. 125 Vol 4, p 1-249

Cowley PD (1990) The taxonomy and life history of the blue stingray Dasyatis marmorata capensis (Batoidea: Dasyatidae) from southem Africa. MSc thesis, Rhodes University, Grahamstown

Cowper SW (1978) The drift algae communities of seagrass beds in Redfish Bay, Texas. Contrib mar Sci 21:125-132

Cyrus DP (1983) The influence of turbidity on fish distribution in Natal estuaries. PhD thesis, University of Natal, Pietermaritzburg

Cyrus DP, Blaber SJM (1982). Species identification, distribution and abundance of Gerreidae (Teleostei) Bleeker, 1859 in the estuanes of Natal. S Afr J Zool 17:105-116

Cyrus DP, Blaber SJM (1987a). The influence of turbidity on juvenile marine fishes in estuaries, Part 1, Field studies in Lake St. Lucia on the southeastern coast of Africa. J exp mar Biol Ecol 109:53-70

Cyrus DP, Blaber SJM (1987b) The influence of turbidity on juvenile marine fishes in estuaries, Part 2, Laboratory studies, comparisons with field data and conclusions J exp mar Biol Ecol 109:71-91

Cyrus DP, Blaber SJM (1987c) The influence of turbidity on juvenile marine fishes in estuaries of Natal, South Africa. Cont Shelf Sci 7:1411-1416

Cyrus DP, Blaber SJM (1992) Turbidity and salinity in a trop1cal northern Australian estuary and their influence on fish distribution. Estuar coast Shelf Sci 35:545-563

Davies JL (1972) Geographical variation in coastal development. Oliver and Boyd, Edinburgh

Day JH, Blaber, SJM, Wallace JH (1981) Estuarine fishes. In: Day JH (ed) Estuarine ecology with particular reference to southern Africa. AA Balkema, Cape Town, p 197-221

De Villiers G (1987) Harvestung harders Liza richardsoni in the Benguela upwelling region. S Afr J mar Sci 5:852-862

Dexter DM (1990). The effect of exposure and seasonality on sandy beach community structure in Portugal. Cienc Biol Ecol Syst 10:31-50

Dorel D, Koutsikopoulos C, Desaunay Y, Marchand J (1991) Seasonal distribution of young sole (Solea solea (L.)) in the nursery ground of the Bay of Vilaine (northern Bay of Biscay). Neth J Sea Res 27:297-306

Edwards RRC (1973) Production ecology of two Caribbean marine ecosystems. I. Physical environment and fauna. Estuar coast mar Sci 1:303-318

Eleftheriou A, Nicholson MD (1975) The effects of exposure on beach fauna. Cah Biol mar 16:695-710

Eltringham SK (1971) Life in mud and sand. English Universities Press, London

Evans S, Tallmark B (1984) Seasonal dynamics of small vagile predators on marine shallow soft bottom. Holarct Ecol 7 $138-148$

Evans S, Tallmark B (1985) Niche separation within the mobile predator guild on marine shallow soft bottoms. Mar Ecol Prog Ser 23:279-286

Field JG, Clarke KR, Warwick RM (1982) A practical strategy for analysing multispecies distribution patterns. Mar Ecol Prog Ser 8:37-52

Futch CR, Dwinell SE (1977) Nearshore marine ecology at Hutchins [sland, Florida: 1971-1974, IV, Lancelets and fishes. Fla mar Res Publ 24:23

Celdenhuys ND (1973) Growth of the South African maasbanker Trachurus trachurus Linnaeus and age composition of the catches, 1950-1971. Investl Rep Sea Fish Branch S A.fr 101:1-24

Gibson RN (1973) The intertidal movements and distribution of young fish on a sandy beach with special reference to the plaice (Pleuronectes platessa L.). J exp mar Biol Ecol 12:79-102

Gibson RN, Ansell AD, Robb L (1993) Seasonal and annual variations in abundance and species composition of fish and macrocrustacean communities on a Scoltish sandy beach. Mar Ecol Prog Ser 98:89-105

Gibson RN, Robb L 1992 The relationship between body size, sediment grain size and the burying ability of juvenile plaice, Pleuronectes platessa L. J Fish Biol 40:771-778 
Gunter G (1945) Studies on the marine fishes of Texas. Publ Inst mar $\mathrm{Scl}$ Univ Texas 1:1-190

Gunter $G$ (1958) Populations studies of the shallow water fishes of an outer beach in southern Texas. Publ Inst mar Sci Univ Texas 5:186-193

Hecht I (1977) Contributions to the biology of the Cape gurnard, Trigla capensis (Pisces: Triglidae): age, growth and reproduction. Zool Afr 12:373-382

Hedgepeth JW (1957) Sandy beaches. In: Hedgepeth JHW (ed) Treatise on marine ecology and palaeociology. Geol Soc Am Mem 67:587-608

Hillman RE, Davis NW, Wennemer J (1977) Abundance, diversity and stability in shore-zone fish communities in an area of Long Island Sound affected by discharge of a nuclear power station. Estuar coast Shelf Sci 5:355-381

Hull SC (1987) Macroalgal mats and species abundance: a field experiment. Estuar coast Shelf Sc1 25:519-532

Hunter JR, Wisby WJ (1964) Net avoidance behaviour of carp and other species of fish. J Fish Res Bd Can 21:613-633

Joubert CSW (1981) Aspects of the biology of five species of inshore reef fishes on the Natal coast, South Africa. Investl Rep oceanogr Res Inst S Afr 51:1-16

Lamberth SJ, Bennett BA, Clark BM (1994) Catch composition of the commercial beach-seine fishery in False Bay, South Africa. S Afr J mar Sci 14:69-78

Lamberth SJ, Bennett BA, Clark BM, Jansens MP (1995) The impact of beach-seine netting on the benthic flora and fauna of False Bay. S Afr J mar Sci 15:115-122

Lasiak TA (1981) Nursery grounds of juvenile teleosts: evidence from the surf-zone of King's Beach, Port Elizabeth S Afr J Sci 77:388-390

Lasiak TA (1982) Structural and functional aspects of the surf zone fish community in the eastern Cape. PhD thesis. University of Port Elizabeth

Lasiak TA (1984a) Structural aspects of the surf-zone fish assemblage at King's Beach, Algoa Bay, South Africa: long term fluctuations. Estuar coast Shelf Sci 18:459-483

Lasiak TA (1984b) Structural aspects of the surf-zone fish assemblage at King's Beach, Algoa Bay, South Africa: short term fluctuations. Estuar coast Shelf Sci 18:347-360

Lasiak TA (1986) Juveniles, food and the surf-zone habitat: implications for teleost nursery areas. S Afr J Zool 21 $51-56$

Lenanton RCJ (1982) Alternative non-estuarine nursery habitats for some commercially and recreationally important fish species of south-western Australia. Aust $J$ mar Freshwat Res 33:881-900

Lenanton RCJ, Caputi N (1989) The roles of food supply and shelter in the relationship between fishes, in particular Cnidoglanis macrocephalus (Valenciennes), and detached macrophytes in the surf zone of sandy beaches. J exp mar Biol Ecol 128:165-176

Lenanton RCJ, Robertson Al, Hansen JA (1982) Nearshore accumulations of detached macrophytes as nursery areas for fish. Mar Ecol Prog Ser 9:51-57

Littler MM, Martz DR, Littler DS (1983) Effects of recurrent sand deposition on rocky intertidal organisms: importance of substrate heterogeneity in a fluctuating environment. Mar Ecol Prog Ser 11:129-139

Lockwood SJ (1974) The settlement, distribution and movements of 0-group plaice Pleuronectes platessa (L) in Filey Bay, Yorkshire. J Fish Biol 6:465-477

Lyons $J$ (1986) Capture efficiency of a beach-seine for seven freshwater fishes in a north-temperate lake. $N$ Am J Fish Manage 6:288-289

Mann BQ (1992) Aspects of the biology of two inshore sparid fishes (Diplodus sargus capensis and Diplodus cervinus hottentotus) off the south-east coast of South Africa. MSc thesis, Rhodes University, Grahimstown

Margalef R (1958) Information theory in ecology. Gen Syst 3 $36-71$

McFarland WN (1963) Seasonal change in the number and biomass of fishes from the surf at Mustang Island, Texas. Publ Inst mai Sci Univ Texas 9:91-105

McHugh JL (1967) Estuarine nekton. In: Lauff G (ed) Estuaries. Am Ass Adv Sci, Washington, DC

McLachlan A (1980) The definition of sandy beaches in relation to exposure: a simple rating system. S Afr J Sci $76: 137-138$

McLachlan A, Cockcroft AC, Malan DE (1984) Benthic faunal response to a high energy gradient. Mar Ecol Prog Ser 16 : $51-63$

McQuaid CD, Dower KM (1990) Enhancement of habitat heterogeneity and species richness on rocky shore inundated by sand. Oecologia $84: 142-144$

Modde $\mathrm{T}$ (1980) Growth and residency of juvenile fishes within a surf zone habitat in the Gulf of Mexico. Gulf Res Rep 6:377-385

Modde I. Ross ST (1981) Seasonality of fishes occupying a surf zone habitat in the northern Gulf of Mexico. Fish Bull US 78:911-922

Morin JG, Kastendiek JE, Harrington A, Davis N (1985) Organization and patterns of interaction in a subtidal sand community on an open coast. Mar Ecol Prog Ser 27:163-185

Panikkar NK (1960) Physiological aspects of adaptation to estuarine conditions. Aust Fish Coun Proc 32:168-175

Pearse AS, Humm HJ, Wharton GW (1942) Ecology of sandy beaches at Beaufort, NC. Ecol Monogr 12:135-190

Penrith MJ, Loutit R (1982) Coastal anglers' catches at Terrace Bay during 1980. Madoqua 13:35-43

Peters DJ, Nelson WG (1987) The seasonality and spatial patterns of juvenile surf zone fishes of the Florida east coast. Fla Sci 50:85-99

Pielou EC (1969) The measurement of diversity in different types of biological collections. I theor Biol 13:131-144

Pierce CL, Rasmussen JB, Leggett WC (1990) Sampling littoral fish with a seine corrections for variable capture efficiency. Can J Fish Aquat Sci 47:1004-1010

Pihl L, van der Veer HW (1992) Importance of exposure and habitat structure for the population density of 0 -group plaice, Pleuronectes platessa L., in coastal nursery areas. Neth J Sea Res 29:145-152

Potter IC, Beckley LE, Whitfield AK, Lenanton RCJ (1990) Comparisons between the roles played by estuaries in the life cycles of fishes in temperate western Australia and southern Africa. Environ Biol Fish 28:143-178

Poxton MG, Nasir NA. (1985) The distribution and population dynamics of 0-group plaice (Pleuronectes platessa L.) on nursery grounds in the Firth of Forth. Estuar coast Shelf Sci 21:845-857

Riley JD, Holford BH (1965) A sublittoral survey of Port Erin Bay, particularly as an environment for young plaice. Rep mar Biol Sta Port Erin 77:49-53

Robertson Al, Hansen JA (1982). Decomposing seaweed a vital link in coastal food chains? CSIRO mar Lab Rep 1979-1981 CSIRO Marine Laboratories, Cronulla, p 75-83

Robertson AI, Lenanton RCJ (1984) Fish community structure and food chain dynamics in the surf-zone of sandy beaches: the role of aquatic macrophyte detritus. J exp mar Biol Ecol 84:265-283

Romer GS (1990) Surf zone fish community and species response to a wave energy gradient. J Fish Biol 36: $279-287$ 
Romer GS, McLachlan A (1986) Mullet grazing on surf diatom accumulations. J Fish Biol 28:93-104

Ross ST (1983). A review of surf-zone ichthyofaunas in the Gull of Mexico. In: Shabica SV, Cofer NB, Cake EW Jr (eds) Proceedings of the northern Gulf of Mexico estuarles and barrier islands research conference. US Dept Int Nat Park Ser, Southeast Regional Office, Atlenta, p 25-34

Ross ST, McMichael RH, Ruple DL (1987) Seasonal and diel variation in the standing crop of fishes and macroinvertebrates from a Gulf of Mexico surf-zone. Estuar coast Shelf Sci 25:391-412

Schulze BR (1965) Clmate of South Africa, Part 8, General Survey. Weather Bureau Publication 28, Pretoria

Senta T, Kinoshita I (1.985) Larval and juvenile fishes occurring in surf zones in western Japan. Trans Am Fish Soc 114:609-618

Shannon LV, Hennig HF-KO, Shillington FA. Bartels A, Swart DH (1991) Colour fronts in False Bay: origin, development and implications. Trans R Soc S Afr 47:447-469

Simpson EH (1949) Measurement of diversity. Nature 163:688

Spargo PE (1991) False Bay, South Africa - an historic and scientific overview. Trans R Soc S Afr 47:363-375

Springer VG, Woodburn KD (1960) An ecological study of the fishes of the Tampa Bay area. Florida State Board of Conservation, Marine Laboratories Proceedings, Serial 1

Talbot FH (1955) Notes on the biology of the white stumpnose, Rhabdosargus globiceps (Cuvier), and on the fish fauna of the Klein River estuary. Trans R Soc S Afr 34: $387-407$

Tallmark B, Evans S (1986) Substrate-related differences in antipredator behaviour in two gobiid fish species and the brown shrimp, and their adaptive value. Mar Ecol Prog Ser 29:217-222

Taylor PR, Littler MM (1982) The roles of compensatory mortality, physical disturbance, and substrate retention in the development and organization of a sand-influenced, rocky-intertidal community. Ecology 63:135-146

van der Elst R (1.976) Game fish of the east coast of southern Africa. I. The biology of the elf, Pomatomus saltatrix (Linnaeus), in the coastal waters of Natal. Investl Rep oceanogr Res Inst S Afr 44

van der Elst RP (1988) A guide to the common sea fishes of southern Africa. Struik, Cape Town

van der Lingen CD (1994) Aspects of the early life history of the galjoen Dichistius capensis. S Afr J mar Sci 14:37-46

van der Merwe D, McLachlan A (1987) Significance of freefloating macrophytes in the ecology of a sandy beach surf zone. Mar Ecol Prog Ser 38:53-63

This article was submitted to the editor van der Veer HW, Bergman MJN, Dapper R, Whitte JIJ \{1991) Population dynamics of an 0-group flounder Platichthys flesus population in the western Wadden Sea. Mar Ecol Prog Ser 73:141-148

Wallace JH (1967a) The batoid fishes of the east coast of southern Africa. Part I: Sawfishes and guitar fishes. Investl Rep oceanogr Res Inst S Afr 15:1-32

Wallace JH (1967b) The batold fishes of the east coast of southern Africa. Part II: Manta, eagle, duckbill, cownose, butterfly and stingrays. Invest Rep oceanogr Res Inst 16: $1-56$

Wallace JH (1975) The estuarine fishes of the east coast of South Africa. III. Reproduction. Investl Rep oceanogr Res Inst S Afr 41:1-51

Wallace JH, Kok HM, Buxton CD, Bennett BA (1984) [nshore small-mesh trawling survey on the Cape south coast. Part 1. Introduction, methods, stations and catches. S Afr J Zool 19:154-164

Warfel HE, Merriman D (1944) Studies on the marine resources of southern New England. 1. An analysis of the fish populations of the shore zone. Bull Bingham Oceanogr Coll 9:1-91

Weng HT (1990) Fish in shallow areas in Moreton Bay, Queensland and factors affecting their distribution. Estuar coast Shelf Sci 30:569-578

Whitfield AK (1990) Life history styles of fishes in South African estuaries. Environ Biol Fish 28:295-308

Whitfield AK, Blaber SJM, Cyrus DP (1981) Salinity ranges of some southern African fish species occurring in estuaries. S Afr J Zool 16:151-155

Wilkinson L (1990) SYSTAT: The system for statistical evaluation. SYSTAT, Inc, Evanston, IL

Wright JM (1988) Recruitment patterns and trophic relationships of fish in Sulaibikhat Bay, Kuwait. J Fish Biol 33: $671-687$

Wright JM (1989) Detached chlorophytes as nursery areas for fish in Sulaibikhat Bay, Kuwait. Estuar coast Shelf Sci 28: $185-193$

Zar JH (1984) Biostatistıcal analysis. Prentice-Hall, Englewood Cliffs, NJ

Ziljstra JJ, Dapper R, Whitte JIJ (1982) Settlement, growth and mortality of post-larval plaice (Pleuronectes platessa) in the western Wadden Sea. Neth J Sea Res 15 250-272

Zobell CE (1971) Drift seaweeds on San Diego county beaches. In: North WJ (ed) The biology of giant kelp beds (Macrocystis) in Calıfornia. Nova Hedwigia 32 (Suppl): $269-314$

Manuscript first received: February 8, 1995

Revised version accepted: July 28, 1995 